To be published in the International and Comparative Law Quarterly

\title{
The Influence of Teachings of Publicists on the Development of International Law
}

\author{
Sandesh Sivakumaran*
}

\section{Introduction}

Once upon a time, the teachings of publicists were considered hugely significant. The writings of Suarez, Grotius, and Vattel, for example, had a profound effect on the structure and content of international law. In the nineteenth century, judicial decisions and the literature were littered with references to the founding fathers and 'resemble[d] catalogues of the praises of famous men' ${ }^{1}$ This continued into the early part of the twentieth century: 'Hear also what Hall sayeth. Hear the comfortable words of Oppenheim' was a reflection of the literature and case law of the period. ${ }^{2}$

By the late twentieth century, the common view, including among publicists themselves, was that the teachings of publicists had become far less influential. ${ }^{3}$ The decline in influence, it is said, is due to the maturation of international law since the era of the founding fathers. With the growth in the number of courts and tribunals that operate, and the rich jurisprudence that comes with it, there is less of a need to turn to the teachings of publicists. ${ }^{4}$ The influence that publicists have on the development of international law at present is contested. Some suggest that scholars 'may be tempted to see their offerings as more influential than they really are', ${ }^{5}$ while others contend that the significance of publicists' work tends to be downplayed, ${ }^{6}$ even that publicists 'typically have an unjustified modesty about their own influence'. ${ }^{7}$

Part of the difficulty in gauging the influence of the teachings of publicists is that the category is not a homogenous one. There are very many 'publicists' of rather different types. This is the focus of Part 2. It is well-accepted that not all publicists are of equal stature: there are publicists and there are publicists. This does not mean simply that certain publicists are more influential than others that hardly need be said. Rather, there are different types of publicists. This article contends that the category of publicist can be broken down into at least three types: entities that have been empowered by states to conclude teachings, such as the International Law Commission; expert groups, both standing and ad hoc; and 'ordinary' publicists.

Regard must also be had to the different types of 'teachings' of publicists. This is the subject of Part 3. Much has been made of teachings that canvass state practice. In a passage from the Paquete Habana, which has been often repeated, the US Supreme Court observed that, 'where there is no

\footnotetext{
* Professor of Public International Law, University of Nottingham.

${ }^{1}$ C Parry, The Sources and Evidences of International Law (Manchester University Press, 1965) 103.

${ }^{2}$ Ibid.

${ }^{3}$ See eg K Wolfke, Custom in Present International Law (Martinus Nijhoff, 1993) 76; A Aust, Handbook of International Law (CUP, 2010) 9.

${ }^{4}$ See eg DP O'Connell, International Law: Volume One (Stevens and Sons, 1965) 34; Parry, above note 3, 104. See also, L Oppenheim, 'The Science of International Law: Its Task and Method' (1908) 2 AJIL 313, 315, noting that, in the absence of international courts, writers take the place of judges.

${ }^{5} \mathrm{~J} d$ 'Aspremont, Formalism and the Sources of International Law (OUP, 2011) 210.

${ }^{6} \mathrm{M}$ Wood, 'Teachings of the Most Highly Qualified Publicists (Art. 38(1) ICJ Statute)', MPEPIL (online), para. 16.

7 'Scholars in the Construction and Critique of International Law: Remarks of Bruno Simma' (2000) 94 ASIL

Proceedings 317, 319.
} 
treaty and no controlling executive or legislative act or judicial decision, resort must be had to the customs and usages of civilized nations, and, as evidence of these, to the works of jurists and commentators who by years of labor, research, and experience have made themselves peculiarly well acquainted with the subjects of which they treat. Such works are resorted to by judicial tribunals not for the speculations of their authors concerning what the law ought to be, but for trustworthy evidence of what the law really is. ${ }^{8}$ However, as with the category of publicists, teachings are also of different types. They include digests, which do canvass state practice, but also treatises, textbooks, monographs, commentaries, journal articles, and blog posts. It is important to break down the category of 'teaching' into its various types, as different types of teachings serve different purposes and are of benefit to different audiences.

Only by breaking down the category of teachings of publicists into its various types can their influence on the development of international law be properly gauged.

A second major difficulty with the determination of the influence of teachings relates to the assessment of 'influence'. The standard view in the literature is to assess influence by the extent to which teachings are cited by courts and tribunals, particularly by the International Court of Justice. Brownlie's Principles of Public International Law is typical in this regard:

'Whatever the grounds for caution, the opinions of publicists enjoy wide use. Arbitral tribunals and national courts make sometimes copious reference to jurists' writings. National courts are generally unfamiliar with state practice and are ready to rely on secondary sources as a substitute. Ostensibly the International Court might seem to make little or no use of jurists' writings. However this is because of the process of collective drafting of judgments, and the need to avoid an invidious selection of citations. The fact that the Court makes use of writers' work is evidenced by dissenting and separate opinions, in which the "workings" are set out in more detail, and which reflect the Court's actual methods. There are many references to writers in pleadings before the Court."

As will be discussed in Part 4, citation by courts and tribunals is indeed a useful measure of influence. A citation provides the link between the work being cited and the individual doing the citing. However, citation is not the same as influence; and lack of citation does not necessarily mean lack of influence. More importantly, citation by courts and tribunals is only one measure of influence. To focus on courts and tribunals is to focus only on one set of actors that are involved in the development of international law.

A better approach to determining influence, this Article suggests, is to identify the various actors that are involved in the development of international law, such as states, courts, and publicists, and analyse the interactions that take place between these actors and the teachings of publicists. It is through this interaction, of which citation is but part, that the influence of the teachings of publicists can properly be determined. In order to demonstrate the continued influence of teachings, breaking with convention, the work of living authors is considered.

\footnotetext{
${ }^{8}$ The Paquete Habana 175 US 677, 700 (1900).

${ }^{9}$ Crawford, Brownlie's Principles of Public International Law (OUP, 2012) 43. See, to similar effect, Wood, above note 6; A Pellet, 'Article 38', in A Zimmermann, C Tomuschat and K Oellers-Frahm (eds), The Statute of the International Court of Justice: A Commentary (OUP, 2006) 868-70.
} 


\section{The notion of 'publicists'}

The notion of a 'publicist', the term that is used in Article 38(1)(d) of the Statute of the International Court of Justice, is an ambiguous one. During the drafting of the Statute of the Permanent Court of International Justice, members of the Advisory Committee of Jurists referred interchangeably to 'authors', 'writers', 'jurists', and 'publicists'. ${ }^{10}$ The Committee agreed on the term 'writers', but this was amended by the Drafting Committee to the term 'publicists'; in both cases the French term 'publicistes' was used. ${ }^{11}$ The Committee did not expand on the meaning of the term. ${ }^{12}$ Over time, the notion of a 'publicist' has been interpreted broadly. It has been taken to include publicists in the ordinary sense, that is to say a textbook writer or an author of a learned monograph; but also bodies such as the International Law Commission, ${ }^{13}$ the International Committee of the Red Cross, ${ }^{14}$ the International Law Association, ${ }^{15}$ and the Institut de Droit International. ${ }^{16}$

This Article contends that the category of publicist can be broken down into at least three broad subcategories: entities that have been empowered by states to produce teachings; expert groups; and ordinary writers. ${ }^{17}$ Furthermore, it is important to break down the category of publicist in order to identify the particular contribution of each type of publicist to the development of international law.

\subsection{State-empowered entities}

The first category of publicist is the publicist that has been empowered by states to draw up a particular teaching. A number of entities have been created by states, or otherwise later empowered by states, and 'granted authority to make decisions or take actions, such as developing, interpreting, applying, and enforcing international law. ${ }^{18}$ These entities are of different types, and some of the work they undertake involves the conclusion of teachings.

\footnotetext{
${ }^{10}$ Advisory Committee of Jurists, Procès-Verbaux of the Proceedings of the Committee: June $16^{\text {th }}-J$ uly $24^{\text {th }}$ 1920 (1920) 323, 351, 332, 319.

${ }^{11} \mathrm{Ibid}, 337$ and 567.

${ }^{12}$ However, one member, de Lapradelle, did refer to the work of the Institut de Droit International in this regard. See ibid, 336.

${ }^{13}$ Wood, above note 6, para. 11. Crawford, above note 9,43 considers the work of the ILC to be '[a] source analogous to the writings of publicists'.

${ }^{14}$ Serdar Mohammed and Others v Secretary of State for Defence [2015] EWCA Civ 843, para. 171; AZ Borda, 'A Formal Approach to Article $38(1)(d)$ of the ICJ Statute from the Perspective of the International Criminal Courts and Tribunals' (2013) 24 EJIL 649, 656-7.

${ }^{15}$ Wood, above note 6, para. 11; M Sourang, 'Jurisprudence and Teachings', in M Bedjaoui (ed), International Law: Achievements and Prospects (UNESECO, 1991) 285.

${ }^{16}$ Wood, above note 6, para. 11; Sourang, above note 15, 285.

${ }^{17}$ Some authors distinguish between different types of scholarship, namely 'academic scholarship', that is to say 'pure academic research' and 'scholarship of action', which includes 'the work of the International Law Commission (ILC) or the Institute of International Law, for example, or individual opinions of international judges ... or possibly amicus briefs by individuals, experts, or non-governmental organizations.' See C Stahn and E De Brabandere, 'The Future of International Legal Scholarship: Some Thoughts on "Practice", "Growth", and “Dissemination"' (2014) 27 LJIL 1, 2, referring to A Oraison, 'Réflexions sur "la doctrine des publicistes les plus qualifiés des différentes nations" (flux et reflux relatifs des forces doctrinales académiques et finalisée)' (1991) 24 RBDI 509.

${ }^{18}$ A Roberts and S Sivakumaran, 'Lawmaking by Nonstate Actors: Engaging Armed Groups in the Creation of International Humanitarian Law’ (2012) 37 Yale JIL 107, 116.
} 
The International Law Commission (ILC), for example, was established by the UN General Assembly, which was itself established by states. ${ }^{19}$ It has a mandate to codify and progressively develop international law, ${ }^{20}$ and, on this basis, has produced draft Articles and other works. Another example is the Office of the UN High Commissioner for Refugees (UNHCR), which was created by the UN General Assembly and is empowered to promote 'the conclusion and ratification of international conventions for the protection of refugees, supervising their application and proposing amendments thereto'. ${ }^{21}$ At the suggestion of a state, UNHCR's Executive Committee, itself composed of states, requested UNHCR 'to consider the possibility of issuing-for the guidance of governments-a handbook relating to procedures and criteria for determining refugee status. ${ }^{22}$ UNHCR thus published its Handbook on Procedures and Criteria for Determining Refugee Status under the 1951 Convention and the 1967 Protocol Relating to the Status of Refugees. ${ }^{23}$ The International Committee of the Red Cross (ICRC) is of a somewhat different order, but still falls within the notion of a stateempowered entity. Although the ICRC was created by a group of private individuals and not by states, it was later empowered by states to carry out various functions, thus satisfying the 'empowerment' aspect of a state-empowered entity. The Statutes of the International Red Cross Movement, which were adopted by the International Conference of the Red Cross, ${ }^{24}$ provide that the role of the ICRC is 'to work for the understanding and dissemination of knowledge of international humanitarian law applicable in armed conflicts and to prepare any development thereof' and 'to carry out mandates entrusted to it by the International Conference'. ${ }^{25}$ With this mandate in mind, the ICRC has published Commentaries on the Geneva Conventions and Additional Protocols and, at the request of the International Conference of the Red Cross and Red Crescent, a Study on Customary International Humanitarian Law.

There are numerous instances of a teaching of a state-empowered entity positing the existence of a norm, or suggesting an idea, before being picked up by states or in a judicial decision. The ILC, for example, has introduced many a novel idea into general international law. Today, the starting point of any discussion on the law of state responsibility is the ILC's Articles on that subject. Indeed, a 2007 report of the UN Secretary-General found that the draft articles had been cited in some 129 cases. ${ }^{26}$ Outside the topic of state responsibility, states have concluded treaties on the basis of ILC draft Articles, including the Vienna Convention on the Law of Treaties (1969), the Vienna Convention on Diplomatic Relations (1961), and the UN Convention on Jurisdictional Immunities of States and their

\footnotetext{
${ }^{19}$ It is thus a second-level state-empowered entity.

${ }^{20}$ Statute of the International Law Commission, Article 1(1), annexed to GA Res 174 (II) (1947).

${ }^{21}$ Statute of the Office of the United Nations High Commissioner for Refugees, annexed to GA Res 428 (V) (1950), Article 8(a).

${ }^{22}$ UNHCR Executive Committee, Conclusion No 8 (XXVIII) Determination of Refugee Status (1977), para. (f). See GS Goodwin-Gill, 'The Search for the One, True Meaning ...', in GS Goodwin-Gill and H Lambert, The Limits of Transnational Law (CUP, 2010) 210-12.

${ }^{23} \mathrm{HCR} / \mathrm{IP} / 4 /$ Eng/REV.1 (1979), re-edited (January 1992).

${ }^{24}$ The International Conference comprises states parties to the Geneva Conventions, the ICRC, the International Federation of the Red Cross and Red Crescent, and national Red Cross and Red Crescent Societies.

${ }^{25}$ Statutes of the International Red Cross Movement, Article 5(2)(g) and (h), adopted at the $25^{\text {th }}$ International Conference of the Red Cross (1986) (as amended).

${ }^{26}$ Responsibility of States for internationally wrongful acts: Compilation of decisions of international courts, tribunals and other bodies, Report of the Secretary-General, A/62/62, 1 February 2007. Later compilations have updated the citation count. See $A / 65 / 76$ and $A / 68 / 72$.
} 
Property (2004). Terminology used by the ILC, such as 'contracting state', 'provisional application' and 'consent to be bound' in the law of treaties, has also passed into general international law. ${ }^{27}$

The teachings of state-empowered entities are thus of a different order to the teachings of publicists without a connection to a state. ${ }^{28}$ Indeed, from a non-formalist perspective, state-empowered entities might best not be considered publicists at all. State-empowered entities have a close relationship with states in a way that ordinary publicists do not. They are empowered by states to carry out a law-making function broadly defined - for present purposes, to develop a teaching. States usually have a say in the election or appointment of individuals to the entity. States also have a role to play in the content of the teaching, for example, submitting their views to the entity or otherwise being involved in the drafting process. In addition, states have an important role to play following the finalization of the teaching, for example, accepting it or rejecting it. ${ }^{29}$

Thus, the teachings of state-empowered entities prove useful, in part, because they can be traced back to states. The importance of the mandate of the entity comes through from cases in which the teachings of state-empowered entities have been cited. For example, in the House of Lords, Lord Steyn expressed the view that '[i]t is not surprising ... that the UNHCR Handbook ... has high persuasive authority, and is much relied on by domestic courts and tribunals' because '[u]nder articles 35 and 36 of the [Refugee] Convention, and under article II of the Protocol of 1967, the UNHCR plays a critical role in the application of the Refugee Convention' and that '[c]ontracting states are obliged to co-operate with $\mathrm{UNHCR}^{30}{ }^{30}$ Also important is the expertise of the entity, suggesting a certain level of knowledge, experience, and reputation. Justice Kirby of the High Court of Australia thus referred to the UNHCR Handbook and Guidelines because 'of the expertise of the UNHCR in the application of the Convention', the competence of UNHCR to ensure a 'correct' interpretation of the Convention, and the obligation of states parties to the Refugee Convention to co-operate with UNHCR and facilitate 'its duty of supervising the application of the provisions of [the] Convention' ${ }^{31}$ Along similar lines, particular weight is given to the views of the ICRC 'given its role in the development of international humanitarian law and the initiatives it has taken'. ${ }^{32}$

\subsection{Expert groups}

A second category of publicist is the expert group or learned society that does not have a mandate from states. The category in question includes groups that are permanent in nature, such as the Institut de Droit International and the International Law Association, as well as groups that are established to carry out a specific project and then cease to operate, such as the group that

\footnotetext{
${ }^{27}$ Pronto and Wood, The International Law Commission 1999-2009 (OUP, 2011) 4.

${ }^{28}$ Along similar lines, Wood, above note 6, para. 12 , has noted that ' $[\mathrm{t}$ ] he product of the ILC has a particular standing, given its position as a subsidiary organ of the UN General Assembly its special relationship with governments and the United Nations Sixth Committee, and the fact that its product is not infrequently adopted as a convention or otherwise endorsed by the General Assembly.'

${ }^{29}$ On the interaction between different actors within the community of international lawyers, see below, Part 4.

${ }^{30} R v$ Secretary of State for the Home Department ex $p$ Adan [2001] 2 AC 477, 520 per Lord Steyn. See also $R v$ Asfaw [2008] UKHL 31, para. 13, per Lord Bingham; Al Sirri v Secretary of State for the Home Department [2012] UKSC 54, para. 36.

${ }^{31}$ Minister for Immigration and Multicultural and Indigenous Affairs v Qaah of 2004 [2006] HCA 53, para. 76.

${ }^{32}$ Serdar Mohammed, above note 14, para. 171.
} 
produced the Maastricht Principles on Extraterritorial Obligations of States in the area of Economic, Social, and Cultural Rights.

Expert groups have not infrequently been the originators of new norms, approaches, and ideas. The International Law Association's Helsinki Rules on the Uses of the Waters of International Rivers (1966) is a case in point. ${ }^{33}$ The Rules have been recognized as constituting customary international law, ${ }^{34}$ and have influenced states in their adoption of instruments. ${ }^{35}$ The Helsinki Rules also influenced the ILC'S work on the subject; ${ }^{36}$ and the UN Convention on the law of the nonnavigational uses of international watercourses is based on the work of the ILA, the Institut de Droit International, and the ILC. ${ }^{37}$

Another pertinent example is the group of experts that drafted the San Remo Manual on International Law applicable to Armed Conflicts at Sea. The military manuals of states published since the adoption of the San Remo Manual draw heavily on it. For example, the UK Manual on the Law of Armed Conflict notes that ' $[\mathrm{t}$ ] he San Remo Manual is a valuable reference work and much of the present chapter reflects its content. When appropriate and possible the text of the San Remo Manual has been repeated in this chapter. ${ }^{38}$ For its part, the Canadian Manual provides that the chapter on the law relating to the conduct of hostilities at sea is 'derived from' the San Remo Manual. ${ }^{39}$

The San Remo Manual is a good example of the influence of writings of publicists also because it demonstrates the potential of writings of individual publicists. On the issue of exclusion zones in the law of armed conflict at sea, the group of experts largely based their approach on an article by William Fenrick, who was himself one of the experts. ${ }^{40}$ The group of experts used the Fenrick article 'as the basis for further study' regarding the issue of exclusion zones, ${ }^{41}$ and the influence of Fenrick's article is readily apparent. The rapporteur indicated that he shared the view of Fenrick that 'the exercise of rights by belligerents in the zone are contingent upon a number of conditions' and set

\footnotetext{
${ }^{33}$ Adopted at the $52^{\text {nd }}$ ILA Conference in Helsinki in 1966.

${ }^{34}$ CB Bourne, 'The International Law Association's Contribution to International Water Resources Law' (1996) 36 Natural Resources Journal 155, 215; SMA Salmon, 'The Helsinki Rules, the UN Watercourses Convention and the Berlin Rules: Perspectives on International Water Law' (2007) 23 Water Resources Development 625, 630.

${ }^{35}$ Of particular note are: the 1975 Joint Declaration of Principles for Utilization of the Waters of the Lower Mekong Basin (adopted by the Mekong Committee, composed of Cambodia, Laos, Thailand, and Vietnam); the Southern African Development Community Protocol on Shared Watercourse Systems (1995); and the Agreement between Namibia and South Africa on the Establishment of a Permanent Water Commission (1992). See Bourne, above note 34, 215; Salmon, above note 34, 630.

${ }^{36}$ See ILC, Draft Articles on the Law of Non-navigational Uses of International Watercourses and Commentaries thereto and Resolution on Transboundary Confined Groundwater.

${ }^{37}$ The Preamble of the Convention notes that it is 'Mindful of the valuable contribution of international organizations, both governmental and non-governmental, to the codification and progressive development of international law in this field'. See further Salmon, above note 34, 632.

${ }^{38}$ UK Ministry of Defence, Manual on the Law of Armed Conflict (OUP, 2004), para. 13.2 (fn omitted).

${ }^{39}$ Canada, Law of Armed Conflict (2001) para. 801.2.

${ }^{40}$ The article is: WJ Fenrick, 'The Exclusion Zone Device in the Law of Naval Warfare' (1986) Canadian Yearbook of International Law 91.

${ }^{41}$ GJF van Hegelsom, 'Introductory Report: Methods and Means of Combat in Naval Warfare', in W Heintschel von Heinegg (ed), Methods and Means of Combat in Naval Warfare: Report and Commentaries of the RoundTable of Experts on International Humanitarian Law Applicable to Armed Conflicts at Sea (UVB, 1992$) 51$.
} 
out the same types of conditions as are discussed in the Fenrick article. ${ }^{42}$ More concretely, the commentary to the section on exclusion zones in the San Remo Manual reproduces passages from the Fenrick article almost verbatim. ${ }^{43}$

The work of some expert groups has thus had a considerable impact on the law. However, the point should not be overstated, as the work of other experts groups has not had a noticeable effect. There does not seem to be an appreciable reason as to why the work of some groups has profoundly influenced the law while the work of other groups, equally distinguished, has not. Indeed, even though certain work-products of a group have exercised influence, other work-products of the same group have not.

The teachings of expert groups are considered to be particularly important and of a different order to those of ordinary publicists. Rosenne, for example, notes that '[i]n the context of the teachings of the most highly qualified publicists, a special place is reserved for the works of scientific organizations devoted to international law', including the ILC, UNCITRAL, the Institute of International Law and the International Law Association. ${ }^{44}$ Along similar lines, Wolfke has noted that draft codifications of scientific societies 'even if not accepted in extenso, are always taken into account, and have a strong bearing on the direction of developments of customary law in the given field of international life. ${ }^{45}$ At the same time, the teachings of expert groups are fundamentally different from the teachings of state-empowered entities due to the lack of a mandate from states to prepare teachings and the inability to trace the teachings back to states.

A number of reasons explain the particular influence of expert groups. Of particular importance is their actual expertise. An expert group has to be made up of 'experts'. For example, the Institut de Droit International is composed of leading international lawyers. The aforementioned group of experts that drafted the San Remo Manual included military lawyers, naval lawyers, government lawyers, ICRC lawyers, and leading academics. In this way, the knowledge and experience of numerous individuals, of various backgrounds, is accumulated and a shared view of the law is presented. If a large number of recognized experts have indicated the state of the law in a particular teaching, it becomes more difficult - though by no means impossible - to disagree with it.

The composition of the expert group can also prove important. Where the composition of the group takes into account geographical distribution, it is likely to be considered more representative and thus potentially more influential than a group that is solely from the global north or global south. ${ }^{46}$ It also avoids the criticism that is not infrequently directed at individual publicists, namely that a

\footnotetext{
42 Ibid. Cf Fenrick, above note 40, 124.

${ }^{43}$ Compare San Remo Manual on International Law Applicable to Armed Conflict at Sea (CUP, 1995) paras 106.2 and 106.5, with Fenrick, above note 40, 125.

${ }^{44}$ S Rosenne, The Perplexities of Modern International Law (Martinus Nijhoff, 2004) 53. See also, to similar effect, Wood, above note 6, para. 11; Werle and Jessberger, Principles of International Criminal Law (OUP, 2014) 60. As noted above, the present article considers groups that have been empowered by states to carry out law-making functions, in this context, to produce teachings, to be of a separate category.

${ }^{45}$ Wolfke, above note $3,76$.

${ }^{46}$ For example, the composition of the International Group of Experts that drafted the Tallinn Manual on the International Law Applicable to Cyber Warfare has been criticised for being western. See eg R Liivoja and T McCormack, 'Law in the Virtual Battlespace: The Tallinn Manual and the Jus In Bello' (2012) 15 YIHL 45, 57.
} 
nationalist position is being taken. ${ }^{47}$ This is of particular importance when strongly divergent views are held on the issue under consideration.

The process through which the teaching is created is also of relevance. If interested actors have an opportunity to feed into the process that gives rise to the teaching, it not only makes it more rigorous and more realistic, but is more likely to lead to their buy-in to the final product. This includes having interested actors participate as members or observers of expert groups, provide comments on drafts, or otherwise feed into the process.

\subsection{The 'ordinary' publicist}

Perhaps the category which is most familiar is that of the 'ordinary' publicist. ${ }^{48}$ Teachings of individual publicists also contribute to the emergence of new ideas. For example, the tripartite 'respect, protect and fulfil' framework, familiar to anyone working with economic, social, and cultural rights, has its origins in work by Henry Shue and Asbjørn Eide. In a book published in 1980, Shue referred to duties 'to avoid depriving', 'to protect from deprivation', and 'to aid the deprived'. ${ }^{49}$ He thus moved the discussion away from a single duty for each right. Around the same time, Eide developed the three-fold typology that is used today - the obligation to respect, protect and fulfil. ${ }^{50}$ He published the typology in academic writing, ${ }^{51}$ and later in a report in his capacity as Special Rapporteur of the Sub-Commission on Prevention of Discrimination and Protection of Minorities. ${ }^{52}$ This tripartite framework has been followed, among others, by the Committee on Economic, Social and Cultural Rights, ${ }^{53}$ and now reflects orthodox thinking on the subject.

Along related lines, the right to development has been traced back to a lecture by Keba M'Baye at the International Institute of Human Rights. ${ }^{54}$ In that lecture, subsequently published, M'Baye distinguished between 'le droit du développement' and 'le droit au développement' and argued for a right to development. A few years later, the Commission on Human Rights, under the chairmanship of M'Baye, adopted a resolution which recommended that ECOSOC invite the Secretary-General to undertake a study on the matter. ${ }^{55}$ A study was prepared, ${ }^{56}$ which was considered by the Commission, and a resolution adopted, which 'reiterate[d] that the right to

\footnotetext{
${ }^{47}$ On which, see Parry, above note 1, 104-5. See also Crawford, above note 9, 43.

${ }^{48}$ The terms 'ordinary' publicist and 'individual' publicist are used to differentiate that category from the category of state-empowered entity and expert group publicist. The writing of an 'individual' publicist is not limited to sole-authored works.

${ }^{49}$ H Shue, Basic Rights: Subsistence, Affluence and U.S. Foreign Policy (Princeton UP, 2 ed, 1996) 52.

${ }^{50}$ Eide has provided an account of the development. See A Eide, 'State Obligations Revisited', in WB Eide and U Kracht (eds), Food and Human Rights in Development: Volume II (Intersentia, 2007) 146.

${ }^{51}$ A Eide, 'The International Human Rights System', in A Eide et al, Food as a human right (UNU, 1984) 154.

${ }^{52}$ Report on the Right to Adequate Food as a Human Right, E/CN.4/Sub.2/1987/23, 7 July 1987.

${ }^{53}$ CESCR, General Comment No 12: The Right to Adequate Food (Art. 11), E/C.12/1999/5, 12 May 1999. The Committee refers to the Report on the Right to Adequate Food as the basis for the tripartite categorisation.

${ }^{54}$ Published as: K M'Baye, 'Le Droit au Developpment comme un Droit de L'Homme' (1972) 5 Revue des Droits de l'Homme 503. The author and the article are credited by many as first advancing the idea of a right to development. See eg J Donnelly, 'In Search of the Unicorn: The Jurisprudence and Politics of the Right to Development' (1985) 15 California Western International Law Journal 473; ID Bunn, The Right to Development and International Economic Law (Hart Publishing, 2012) 40-4.

${ }^{55}$ Commission on Human Rights, Report on the Thirty-Third Session, E/CN.4/1257 (1977), p.74.

${ }^{56}$ Report of the Secretary-General, E/CN.4/1334 (1979).
} 
development is a human right' $^{57}$ The General Assembly later declared that 'the right to development is a human right', ${ }^{58}$ and some years later, the Declaration on the Right to Development was adopted by 146 votes to 1 with 8 abstentions. ${ }^{59}$

There is no discernible reason as to why the teachings of one individual publicist are taken up and not those of another. However, as will be seen in Part 4.3, an individual publicist who also has another role, such as a member of an expert group, or a UN expert, can have particular influence. As with expert groups, the expertise of an individual publicist and the quality of his or her teachings are of particular importance. The eminence of an individual publicist, usually based on his or her expertise, but also on associated factors such as title and reputation, can also affect the weight to be given to the work. In this way, the user can rest assured that the propositions stated in the work are reliable.

Courts and tribunals not infrequently signal the expertise of an individual publicist through the way in which they are described. Individual publicists are sometimes described as 'eminent ${ }^{\prime 60}$ or 'learned' ${ }^{61}$ Others are introduced by their title of ' $D r^{\prime}$ or 'Professor'. ${ }^{62}$ The job titles or institutional affiliation of still others are included, for example, 'Professor Parry of Cambridge University' or 'the eminent Louis B. Sohn, the emeritus Bemis Professor of International Law at the Harvard Law School'. ${ }^{63}$ In this way, the reader is assured that the individual whose work is being relied upon is someone whose views really can be taken seriously.

Insofar as the qualifier 'the most highly qualified' publicists in Article 38(1)(d) of the Statute of the International Court of Justice is concerned, this is question-begging. ${ }^{64}$ During the drafting of the Statute of the PCIJ, members of the Advisory Committee of Jurists referred to various qualifiers, including 'authors whose opinions have authority', 'qualified author', and 'the best qualified writers', ${ }^{65}$ but each raises questions of their own. Although it might be said that a particular individual is surely a most highly qualified publicist, ultimately, the moniker is subjective. ${ }^{66}$ In practice, the work of many different publicists has been utilised and the focus tends to be more on the quality of a particular teaching than the standing of a particular author.

Ultimately, the category of publicist can be broken down into different types - state-empowered entities, expert groups, and ordinary publicists. It is important to do so as the precise influence of

\footnotetext{
${ }^{57}$ E/CN.4/1408 (1980) 162.

58 GA Res 34/46 (1979).

${ }^{59}$ GA Res 41/128 (1986).

${ }^{60}$ Eg SRYYY v Minister for Immigration and Multicultural and Indigenous Affairs, Judgment [2005] FCAFC 42, ILDC 981.

${ }^{61}$ Eg $R$ v Bow Street Metropolitan Stipendiary Magistrate and Others, ex parte Pinochet Ugarte (No 3) [2000] AC 147, 283 per Lord Phillips.

${ }^{62}$ Eg Adalah (Legal Center for Arab Minority Rights in Israel) and ors v General Officer Commanding Central Command, Israeli Defence Force and ors, Original Petition, HCJ 3799/02, ILDC 155.

${ }^{63}$ United States v Yousef 327 F.3d 56 (4 April 2003) paras 126 and 127.

${ }^{64}$ But compare Oppenheim, The Science of International Law, above note 4, 345, drawing the distinction between 'writers at large and writers of authority'.

${ }^{65}$ Procès-Verbaux, above note 10, 323, 336, 337.

${ }^{66}$ Parry, above note 1,108 , has suggested that 'it is as difficult to decide who "the most highly qualified publicists" are as it is to say what is a peace-loving nation within the meaning of the Charter of the United Nations.'
} 
teachings of publicists varies depending on the particular type of publicist as well as the specific type of teaching. To teachings we now turn.

\section{Teachings of the 'ordinary' publicist}

In one of the classic quotes on the teachings of publicists, set out in the introduction, the Supreme Court of the United States referred to the use of writings of publicists as 'evidence' of the 'customs and usages of civilized nations'. ${ }^{67}$ The passage has since been repeated with approval on numerous occasions. ${ }^{68}$ However, just as publicists are of different types, so too are teachings. Not all types of teachings contain evidence of the customs and usages of states and those that do not can prove just as valuable for the development of international law as those that do. Accordingly, it is important to explore the notion of 'teachings', a notion on which little can be discerned from the proceedings of the Advisory Committee of Jurists. Members of the Committee used the terms 'teaching', 'doctrine', 'opinions', and 'works' interchangeably, ${ }^{69}$ but provided little by way of elucidation on their meaning. The French term 'la doctrine' was used, but again without development. ${ }^{70}$ What follows is a nonexhaustive categorisation of the notion. ${ }^{71}$

\subsection{Digests}

International law digests are essentially collections of materials on international law that are selected, edited, arranged, and subjected to analysis. Historically, digests have proven influential in the development of international law. Courts have not infrequently utilized them for their evidence of state practice and the views of states. Government legal advisors also turn to them for precedents. $^{72}$

Particularly influential digests of international law were produced in the United States, authored successively by Wharton, Moore, Hackworth, and Whiteman. ${ }^{73}$ Digests were also produced in other states, such as Clive Parry's A British Digest of International Law (1965). The complete titles of the works are revealing. For example, the full title of Moore's Digest is: A Digest of International Law as embodied in Diplomatic Discussions, Treaties and other International Agreements, International Awards, the Decisions of Municipal Courts, and the Writings of Jurists and especially in Documents, Published and Unpublished, Issued by Presidents and Secretaries of State of the United States, the Opinions of the Attorney-General, and the Decisions of Courts, Federal and State. These works thus provide the evidence of state practice to which the US Supreme Court in the Paquete Habana was referring.

\footnotetext{
${ }^{67}$ The Paquete Habana, above note 8, 700.

${ }^{68}$ See eg Sosa v Alvarez-Machain et al 124 S Ct 2739, 2766.

${ }^{69}$ Procès-Verbaux, above note $10,323,319,344,334$.

${ }^{70}$ Ibid, 567.

${ }^{71}$ It is also somewhat artificial. As will be seen, the categories blend into one another.

${ }^{72}$ LB Sohn, 'Sources of International Law' (1995-6) 25 Georgia Journal of International and Comparative Law 399, 399-401.

${ }^{73}$ MM Whiteman, Digest of International Law (published between 1963 and 1973); GC Hackworth, Digest of International Law (published between 1940 and 1944); JB Moore, A Digest of International Law (1906); F Wharton, A Digest of the International Law of the United States Taken from Documents Issued by Presidents and Secretaries of State and from Decisions of Federal Courts and Opinions (1887).
} 
However, many of these digests were not composed purely of state practice. Rather, the practice was placed in context and accompanied by analysis. Moore's Digest, for example, traced the history of a particular issue, quoted extracts from leading documents, and elucidated the relevant principles. Moore, himself, made the point that 'while the work bears the name and the character of a digest, it also contains much that is of an expository nature, in the form suitable to a treatise. ${ }^{, 74}$ Accordingly, some digests were, in fact, part-digest and part-treatise. As Reisman notes:

"As a title, the word "digest" is really a misnomer. Digests of international law do almost no "digesting". Like the American casebook, they select and reproduce chunks of documents and cases relevant to particular problem areas that the decisionmaker is likely to encounter. In this sense, the digest is a useful counterweight to rule-oriented treatises. The documents and particularly the diplomatic correspondence show human beings applying policies and adapting institutional arrangements to ever-changing situations. So despite its nominal jurisprudence, the digest is much more representative of the actual process of international decisionmaking. ${ }^{75}$

In selecting and reproducing 'chunks of documents', the author of the digest necessarily has to make a choice as to what to include and what to exclude: '[d]ocuments and incidents that could be extremely relevant to subsequent practice may be suppressed or reproduced so selectively that they give the reader quite a different impression of what transpired ${ }^{\prime}{ }^{76}$ The use of different documents, different excerpts, or different arrangements could paint a different picture. Accordingly, the role of the digest-writer is important. Indeed, O'Connell goes so far as to say that 'a mass of historical evidence is inarticulate until it is organised' and that 'it is the intellectual construction rather more than the observation and recording of what are assumed to be facts that gives method and vitality to the growth of rules. ${ }^{177}$

By the twenty first century, the digest, or its equivalent, was of a rather different sort. The digest compiles the practice, statements, and views of the relevant state, but with limited to no context, comment, or analysis. They are more in the nature of a compilation of key documents than a digest in the sense of that described by Moore. This is true of many compilations, including the sections on practice in the various year books of international law. ${ }^{78}$ Context and comment tends to be lacking.

It has thus been suggested that it 'made some sense' to use the writings of scholars 'as a source of international law' 'during the nineteenth century positivist heyday of international law, when scholars did the hard work of collecting international practices' but that it makes 'little sense today' where scholarship in certain fields such as international human rights law is characterized by 'normative rather than positive argument' ${ }^{79}$ However, some digests are put together by state legal advisors rather than scholars. Furthermore, since the heyday of the legal digest, monographs on

\footnotetext{
${ }^{74}$ Moore, above note 73, Vol I, iv.

${ }^{75}$ WM Reisman, 'Lassa Oppenheim's nine lives' (1994) 19 Yale JIL 255, 259.

${ }^{76}$ Ibid.

77 O'Connell, above note 4, 35.

${ }^{78}$ For example, the Australian Year Book of International Law contains a section on 'Australian Practice in International Law'.

79 'Scholars in the Construction and Critique of International Law', Remarks by Jack Goldsmith (2000) 94 American Society of International Law Proceedings 317, 318-9.
} 
specialized areas of international law have become commonplace, ${ }^{80}$ and these often do canvass the relevant state practice. The collection and analysis of state practice thus continues in the teachings of publicists, but not in the form of the digest. Furthermore, international law scholarship has long contained descriptive as well as normative argument. ${ }^{81}$

In any event, teachings of publicists are influential not only for their evidence of state practice. The US Supreme Court in Paquete Habana itself acknowledged another reason to turn to the writings of publicists, namely for 'trustworthy evidence of what the law really is. ${ }^{82}$ Writings also 'give shape and order to the disparate strands that make up international law'. ${ }^{83}$ With the growth of the field and the increase in the number of judicial decisions on the subject, writings serve to order, systematize, and analyse what is taking place. And as Lauterpacht observed in 1956, "[w] hile the availability of other sources of information may have altered the nature of the function of "publicists" as recorders of the practice of States, their part as its qualified interpreters cannot always be disregarded. ${ }^{, 84}$

\subsection{Treatises and textbooks}

Also influential historically were the major treatises on international law. In the nineteenth century, the treatise formed 'the core of learning on international law' ${ }^{85} \mathrm{~A}$ treatise is defined by its method: 'it begins with a definition of the subject matter, and proceeds by logical and systematic stages to cover the whole field ${ }^{\prime 86}$ To recall Reisman once again:

'The modern treatise is a systematic collection of rules. It is based, in its various forms, on a conception of decisionmaking as the application of rules to factual situations, which can be categorized in advance with enough precision so that the rules can be readily applied. The evidence of law is to be found in past decisions, each of which may be juridically analyzed in order to confirm and further clarify the rule in question. ${ }^{, 87}$

As is well known, the founding texts of Grotius, ${ }^{88}$ Pufendorf, ${ }^{89}$ and Vattel, ${ }^{90}$ have been hugely influential. Later, the major works by Bluntschli, ${ }^{91}$ Fiore, ${ }^{92}$ Hall, ${ }^{93}$ Halleck, ${ }^{94}$ Oppenheim, ${ }^{95}$ PradierFodéré, ${ }^{96}$ and Wheaton, ${ }^{97}$ among others, ${ }^{98}$ were all heavily utilized. For example, Oppenheim's

\footnotetext{
${ }^{80}$ See below, Part 3.3.

${ }^{81}$ WJ Aceves, 'Symposium Introduction: Scholarship as Evidence of International Law' (2003) 26 Loyola of Los

Angeles International and Comparative Law Review 1, 4-5.

82 The Paquete Habana, above note $8,700$.

${ }^{83}$ Wood, above note 6 , para. 3.

${ }^{84} \mathrm{H}$ Lauterpacht, The Development of International Law by the International Court (Stevens and Sons, 1958) 25.

${ }^{85}$ A Nussbaum, A Concise History of the Law of Nations (Macmillan, 1947) 236.

${ }^{86}$ TFT Plucknett, Early English Legal Literature (1958) 20.

${ }^{87}$ Reisman, above note 75, 257.

${ }^{88}$ Grotius, De Jure Belli ac Pacis (1625).

${ }^{89}$ Pufendorf, De Jure Naturae et Gentium (1672).

${ }^{90}$ Vattel, Le droit des gens (1773).

${ }^{91}$ Bluntschli, Das moderne Völkerrecht der civilisirten Staaten als Rechtsbuch dargestellt (1868).

92 Fiore, Trattato di diritto internazionale public (1865).

${ }^{93}$ Hall, A Treatise on International Law (1880).

${ }^{94}$ Halleck, International Law (1861).

${ }^{95}$ Oppenheim, International Law (1905).

${ }^{96}$ Pradier-Fodéré, Traité de droit international public (1885).
} 
International Law has been described as 'quoted and relied upon by governments and domestic and international tribunals, often as the final authoritative statement of international law on a particular point', ${ }^{99}$ and as 'by common consent the outstanding and most frequently employed systematic treatise on the subject in the English-speaking countries'. ${ }^{100}$

In certain jurisdictions, such as the United States, treatises have fallen into decline. In 1987, in a review essay entitled 'The Case of the Vanishing Treatises', Franck famously asked '[w]here have all the treatises gone?' ${ }^{101}$ Franck put this down to changes in legal theory and 'legal nihilism' ${ }^{102}$ It has also been suggested that the treatise has been 'superseded' ${ }^{103}$ On this view, the treatise is 'no longer the most efficient or reliable vehicle for the compilation and dissemination of the positive law. ${ }^{104}$ By contrast, in other jurisdictions, such as France and the United Kingdom, treatises that cover the breadth of international law continue to be published. ${ }^{105}$ And changes in authorship of 'venerable texts', such as the Précis Dalloz and the Collection Thémis of the Presses Universitaires de France, constitute 'a major event'. ${ }^{106}$

There is frequently overlap between the leading treatises and the favoured textbooks of the day. Although there are differences between treatises and textbooks - 'there are differences of function (a textbook addresses students) and reach (a treatise claims comprehensiveness) ${ }^{107}$ - there is no clear distinction between the two. ${ }^{108}$ This is evident from a consideration of the major English language treatises and textbooks. Oppenheim wrote the first edition of the text now known by his name as 'an elementary book for those who are beginning to study International Law. It is a book for students written by a teacher. ${ }^{109}$ Its title, however, indicates that it is a treatise. Over time, it has morphed into a practitioner work, with Fitzmaurice describing the eighth edition as 'the practitioner's Bible'; ${ }^{110}$ and Jennings and Watts, the authors of the ninth edition, indicating that they

\footnotetext{
${ }^{97}$ Wheaton, Elements of International Law (1866).

${ }^{98}$ For a list of international law treatises published in the UK between 1800 and 1970, see J Crawford, 'Public International Law in Twentieth-century England', in J Beatson and R Zimmermann, Jurists Uprooted (OUP, 2004) 702.

99 Reisman, above note 75, 256.

${ }^{100}$ Nussbaum, above note 85, 277.

${ }^{101}$ TM Franck, 'Review Essay: The Case of the Vanishing Treatises' (1987) 81 AJIL 763, 763.

102 Ibid, 764-6.

${ }^{103}$ NG Onuf, Book Review of 'Recueil des Cours de l'Académie de Droit International de la Haye, 1989. 5 vols.' (1992) 86 AJIL 834, 834.

104 Ibid.

105 It has been said that 'Nowhere is the art of writing general textbooks and treatises more assiduously practiced than in France'. A de Mestral, Book Review of 'Droit International' (1994) 88 AJIL 553, 553.

${ }^{106}$ Ibid.

${ }^{107}$ C Warbrick, Brownlie's Principles of Public International Law: An Assessment' (2000) 11 EJIL 621, 628.

${ }^{108}$ Warbrick himself notes this. See ibid. Furthermore, the division between treatises and textbooks is not a binary one. See O Sender and M Wood, 'Book Review' (2013) 107 AJIL 959, 962. For example, there are introductions to international law that are intended also for the lay reader, such as Brierly's International Law, most recently the $7^{\text {th }}$ edition by Andrew Clapham.

${ }^{109}$ Oppenheim, above note 95, vii.

${ }^{110}$ GG Fitzmaurice, 'The Foundations of the Authority of International Law and the Problem of Enforcement' (1956) 19 MLR 1, 2.
} 
preserved Oppenheim's 'status as a practitioner's book, rather than as an academic treatise'. ${ }^{111}$ Other works have been written for both students and practitioners. In the first edition of Starke's Introduction, for example, the author notes that he was writing for 'intending international officials, diplomatic recruits, and University students' ${ }^{112}$ Brownlie wrote his Principles of Public International Law for 'ambitious students', ${ }^{113}$ but others have testified to its utility to practitioners. ${ }^{114}$ It is considered a textbook and a treatise. ${ }^{115}$ How it is perceived depends on the reader. ${ }^{116}$ The second edition of Hall's Treatise on International Law is designated a treatise; ${ }^{117}$ but Pearce Higgins, in the eighth edition, writes that the additions he has made should make it 'of greater assistance to students' ${ }^{118}$ Other books have been written very much as practitioner works. ${ }^{119}$

The influence of textbooks should not be underestimated. Judicial decisions tend to refer frequently to the leading textbooks of the day, as do government legal advisors. ${ }^{120}$ As will be seen, the structure, substance, and views set out in a textbook can influence generations of students. ${ }^{121}$ Textbooks thus have the potential to exercise considerable influence.

\subsection{Monographs and edited collections}

Just as the age of the digest has passed, so, too, has the age of the treatise. ${ }^{122}$ By the start of the twenty-first century, the most prevalent form of scholarship was the monograph, the edited collection, and the journal article. Barely a day goes by without the publication of a monograph, an edited collection, a handbook, a guide, a companion, a festschrift, or a variant thereof. ${ }^{123}$ A number of reasons explain this state of affairs, including the digital age and the relative ease of researching and writing; ${ }^{124}$ the growth of the field; increasing specialization; ${ }^{125}$ the increase in the number of individuals working in the area, in academia, in practice, and as students; the related increase in the

\footnotetext{
${ }^{111}$ Sir R Jennings and Sir A Watts, Oppenheim's International Law $\left(9^{\text {th }}\right.$ ed, Longman, 1996) xiii. For some criticism of this, see the review by MW Janis, 'The New Oppenheim and its Theory of International Law' (1996) 16 OJLS 329.

112 JG Starke, An Introduction to International Law (Butterworth and Co, $1^{\text {st }}$ ed, 1947) v.

${ }^{113}$ Warbrick, above note 107, 623.

${ }^{114}$ See eg S Wordsworth QC, 'Book Review' (2013) 2 Cambridge JICL 350, 350 and 354.

${ }^{115}$ For its characterization as a textbook, see Warbrick, above note 107,628 . For its characterization as a treatise, see Review by RR Baxter (1967) 42 BYBIL 333, 333.

${ }^{116}$ Geoffrey R Watson, 'Review Essay: Treatises and Study Aids for American Students of International Law' (2005) 99 AJIL 932, $937 \mathrm{fn}$ 6, has indicated that 'such a book would rarely be used as a "textbook" in the United States, and thus Americans are likely to regard it as a "treatise".'

${ }^{117}$ WE Hall, A Treatise on International Law (Clarendon Press, $2^{\text {nd }}$ ed, 1884). Cf. the first edition, entitled International Law (Clarendon Press, 1880).

${ }^{118}$ AP Higgins, Halls' International Law ( $8^{\text {th }}$ ed, 1924) xi.

${ }^{119}$ See eg O'Connell, above note 4, ix-xv, which contains numerous references to it being a practitioner's work.

${ }^{120}$ Sender and Wood, above note 108, 962.

${ }^{121}$ See below, Part 4.2.3.

122 Writing in 1965, Parry, above note 1, 104, observed that '[w]e have passed out of the age of the institutional writer into that of the specialist monograph.'

123 John Louth, the Editor-in-Chief of Academic Law at Oxford University Press, has identified 401 books that were published on international law in English, French or German between April 2014 and March 2015 alone. See J Louth, 'How Many International Law Books are Published in a Year?', Opinio Juris, 8 April 2015, available at http://opiniojuris.org/2015/04/08/guest-post-how-many-international-law-books-are-published-in-a-year/. 124 JHH Weiler, 'On My Way Out - Advice to Young Scholars II: Career Strategy and the Publication Trap' (2015) 26 EJIL 795, 795.

${ }^{125}$ Stahn and De Brabandere, above note 17, 7.
} 
number of conferences and workshops that take place; the increase in the number of publishing houses and law journals; ${ }^{126}$ and career reasons, ${ }^{127}$ such as the 'publish or perish' phenomenon.

Treatises were not designed to be read from cover to cover. They were more encyclopaedia and less monograph. ${ }^{128}$ Their value lay in being able to dip in and out of them to access information on an as needed basis. By contrast, monographs and journal articles are designed to be read cover to cover, although, in the case of monographs, this perhaps happens more in theory than in practice. ${ }^{129}$

A monograph enables 'a rigorous and extensive presentation of arguments, sustained potentially over a broader set of areas, and placed in context with other important issues, both within and outside of a discipline. ${ }^{130}$ It will include 'detailed discussion on trends and contradictions in jurisprudence, comprehensive accounts of research or scholarship on a given topic, and/or presentations of valuable and interesting historical or statistical data. ${ }^{131} \mathrm{~A}$ monograph tends to focus on one topic, or one specific area of law, and subjects that topic or area to comprehensive analysis. Monographs can serve as repositories of state practice, as 'trustworthy evidence of what the law really is', ${ }^{132}$ and the source of new ideas. Much turns on the individual monograph and the goals of the particular author.

\subsection{Commentaries}

Although a subset of the previous category, there is a special place for Commentaries in the teachings of publicists. Oftentimes, a treaty provision is rather succinct and its meaning is difficult to discern. A teaching that explores the meaning of the provision - looking into its object and purpose, situating it in context, considering its drafting history, analysing subsequent practice, and canvassing relevant literature - can prove influential. It is particularly in the interpretation of the law that Commentaries have proven valuable.

The ICRC Commentaries on the Geneva Conventions under the general editorship of Jean Pictet, and the ICRC Commentaries on the Additional Protocols, are a good example of this. They have been described by courts and tribunals as 'particularly valuable', ${ }^{133}$ even 'authoritative'. ${ }^{134}$ The manner in which the ICRC Commentaries have been used is even more revealing than the terminology used to describe them. The Commentaries are cited and quoted extensively in certain judgments. ${ }^{135}$ In other cases, the Commentaries are treated as determinative. For example, according to the Martić Trial Chamber, on one particular issue, the ICTY Appeals Chamber in Blaškić 'based its holding on the ICRC

\footnotetext{
${ }^{126}$ Ibid, 6; Weiler, above note 124, 795.

127 Ibid.

${ }^{128}$ LB Solum, 'Blogging and the Transformation of Legal Scholarship' (2006) 84 Washington University Law Review 1071, 1075.

${ }^{129}$ See F Baetans and V Prislan, 'The Dissemination of International Scholarship: The Future of Books and Book Reviews' (2014) 27 LIL 559, 559.

130 Ibid, 561.

131 Ibid.

${ }^{132}$ The Paquete Habana, above note 8, 700.

${ }^{133}$ Serdar Mohammed, above note 11, para. 171. See also Haidar Ali Hussein v Secretary of State for Defence [2013] EWHC 95, para. 33 ('long been regarded as a valuable source of determining the correct construction of the various Conventions').

${ }^{134}$ Prosecutor v Tadić, Appeals Chamber, Judgment, IT-94-1, 15 July 1999, para. 93.

${ }^{135}$ See eg Haidar Ali Hussein, above note 133.
} 
Commentary'. ${ }^{136}$ Likewise, in the Stakić Appeal Judgment, the Appeals Chamber noted that ICTY trial judgments on a particular issue 'rely for their authority on a statement in the ICRC Commentary'. ${ }^{137}$

The weight given to the ICRC Commentaries is thus considerable. This is particularly notable as the Commentaries did not in fact represent the official views of the ICRC. ${ }^{138}$ The foreword to the 1952 Commentary on the First Geneva Convention, for example, provides that, "[a]lthough published by the International Committee, the Commentary is the personal work of its authors'. ${ }^{139}$ Likewise, the Foreword to the ICRC Commentary on the Additional Protocols indicates that the ICRC viewed the Commentary 'above all as a scholarly work, and not as a work intended to disseminate the views of the ICRC. ${ }^{140}$ Over time, and in practice, the Commentaries have come to be seen as reflecting the ICRC's view.

Commentaries, generally, tend to be of particular use to courts. For example, Christoph Schreuer's The ICSID Convention: A Commentary has been described as having achieved 'a unique position' in international investment law, being cited in more than 60 awards. ${ }^{141}$ Likewise, Bothe, Partsch and Solf's Commentary is regularly cited by international criminal courts and tribunals, and, at times, is given the same authority as the ICRC Commentary. ${ }^{142}$ As Thirlway notes, 'there are a number of scholarly publications in specialized fields that have obtained the status of being the book on that particular subject, cited by counsel and by tribunals with almost the authority of one of the three sources of international law. ${ }^{143}$

\subsection{Journal articles}

The journal article is the short form of the monograph. Periodicals on international law were established, among other things, in order to make international law accessible to a wider audience. The Foreword to the International Law Quarterly, the predecessor to this Quarterly, stressed the need to increase awareness of international law: 'it is to be hoped that the foundation of this new Quarterly will bring home to a wider section of the community the part which International Law has to play in the modern world, and will lead to an ever increasing knowledge of the rules which it

\footnotetext{
${ }^{136}$ Prosecutor v Martić, Trial Chamber, Judgment, IT-95-11-T, 12 June 2007, fn 137.

${ }^{137}$ Prosecutor v Stakić, Appeals Chamber, Judgment, IT-97-24-A, 22 March 2006, para. 305. See also outside the context of the ICTY, Eritrea Ethiopia Claims Commission, Partial Award, Prisoners of War, Eritrea's Claim 17, 1 July 2003, para. 68.

${ }^{138}$ Indeed, there can be debate as to whether the commentary should even be referred to as the ICRC Commentaries, or rather as the Pictet Commentaries.

${ }^{139}$ ICRC, Commentary I Geneva Convention for the Amelioration of the Condition of the Wounded and Sick in Armed Forces in the Field (ICRC, 1952) 7.

${ }^{140}$ ICRC, Commentary on the Additional Protocols of 8 June 1977 to the Geneva Conventions of 12 August 1949 (ICRC, 1987) Foreword.

${ }^{141} \mathrm{~T}$ Cole, 'Non-binding Documents and Literature', in T Gazzini and E De Brabandere, International Investment Law: The Sources of Rights and Obligations (Martinus Nijhoff, 2012) 305.

${ }^{142}$ For example, in the Mucić Appeal Judgment, the Appeals Chamber noted that ' $\mathrm{t}$ ] he two commentaries on Additional Protocol I appear to agree that the French text which is broader, should be preferred'; the two commentaries being the ICRC Commentary and the Bothe, Partsch and Solf Commentary. See Prosecutor $v$ Mucić et al, IT-96-21-A, Judgment, 20 February 2001, fn 331.

${ }^{143}$ H Thirlway, The Sources of International Law (OUP, 2014) 126-7.
} 
prescribes, so as to strengthen in the international sphere the forces that make for justice through compliance with the law'. ${ }^{144}$

Some years earlier, in the 'Prospectus' for the American Society of International Law, the absence of an English language periodical devoted to international law was noted, as was the importance of a means of communication between jurists and students and the scientific and the lay public. ${ }^{145}$ The 'goal' of the American Journal of International Law was to 'attract readers among legal academics, scholars of international relations and history, government officials, members of military and diplomatic establishments (from both the United States and abroad), staffs of international institutions and nongovernmental organizations, members of the bench and bar, and businessmen and others involved in international commerce and affairs. ${ }^{146}$ This is reflected in the first article in the first issue of the American Journal. Entitled 'The Need of Popular Understanding of International Law', the author, Elihu Root, noted that '[t]he increase of popular control over national conduct, which marks the political development of our time, makes it constantly more important that the great body of the people in each country should have a just conception of their international rights and duties. ${ }^{147}$ Root went on to note that '[o]ne means to bring about this desirable condition is to increase the general public knowledge of international rights and duties and to promote a popular habit of reading and thinking about international affairs. ${ }^{\prime 148}$ Right from the outset, the American Journal saw policymakers, ${ }^{149}$ and lay readers, ${ }^{150}$ as a key part of its audience.

English language international law journals of the period were thus designed to convey information on international law to a wide audience. This necessarily had an impact on the form and content of the periodical. They were published at regular intervals and contained pieces of digestible length. The precise content of the periodical differed from publication to publication, but they tended to contain scholarly articles of differing lengths, recent developments, reviews of the case law, consideration of state practice, and reviews of recent publications. Nonetheless, the mixed audience meant that pieces could not always serve both the specialist and the lay reader. ${ }^{151}$

International law journals published since that time share the same format but differ in focus. For example, the African Journal of International and Comparative Law 'is meant to provide a forum in which African lawyers, scholars and Africanists elsewhere may freely exchange their ideas, regarding International and Comparative Law generally and as they relate to Africa in particular'. ${ }^{152}$ The Asian Journal of International Law 'hopes to provide a forum for debating the world of international law and institutions' and 'aspires to cultivate a conversation between scholars, practitioners and policy-

\footnotetext{
${ }^{144}$ Sir CJB Hurst, 'Foreword' (1947) 1 ILQ 1. For a reflection on the contribution of the Quarterly, see C Redgwell, '60 Years of Legal Scholarship in the International and Comparative Law Quarterly' (2012) 61 ICLQ 1, in particular the assessments by Malcolm Evans and Robert McCorquodale.

145 'Prospectus: The Aim and Scope of the American Society of International Law' (1907) 1 AJIL 130, 131. See also 'History of the Organization of the American Society of International Law' (1907) 1 ASIL Procs 23, 28-30.

${ }^{146}$ DJ Bederman, 'Appraising a Century of Scholarship in the American Journal of International Law' (2006) 100 AJIL 20, 57. See also WW Bishop Jr, 'Editorial Comment' (1962) 56 AJIL 997, 998.

${ }^{147}$ E Root, 'The Need of Popular Understanding of International Law' (1907) 1 AJIL 1, 1.

148 Ibid, 2.

149 Bederman, above note 146, 22.

150 JB Scott, 'Editorial Comment' (1907) 1 AJIL 129, 135. See also History of the American Society of International Law, above note 145, 28-30.

${ }^{151}$ See FL Kirgis, 'The Formative Years of the American Society of International Law' (1996) 90 AJIL 559, 569.

152 General Editor, 'Editorial Comment' (1989) 1 African Journal ICL xix, xix.
} 
makers located in or interested in Asia.. ${ }^{153}$ And the Chinese Journal of International Law was established to enable the international community to access the views and materials of China, to promote mutual understanding, and 'to inform decision-making in international law and relations and promote research and teaching in China'. ${ }^{154}$

As is evident from the goal of each of these journals, the accessibility of a teaching is important. A variety of factors influence accessibility, including the language in which the teaching is written, whether it is electronically available, and whether it is freely available. At a practical level, teachings in one of the more widely-spoken languages, or in multiple languages, will be accessible to a larger audience than writings in a language that are spoken in only a handful of states. This has influenced the language in which particular journals are published, and the language in which authors publish their work. ${ }^{155}$ For example, the International Review of the Red Cross switched from French to English, but publishes annual selections in Arabic, Chinese, French, Russian, and Spanish. ${ }^{156}$ Journals such as the Chinese Journal of International Law are published in English even though they are based in states in which the native language is not English. Indeed, the lack of English language journal of international law emanating from China was a reason for its creation. ${ }^{157}$ This attracts a broader readership and makes use of the articles more likely. Accessibility of teachings is important also in the sense of their being readily locatable. If a teaching is difficult to access, it is less likely to be used. With this in mind, and fitting with its intended readership, the American Journal 'has always received preferential distribution within the U.S. Department of State and to U.S. embassies abroad. ${ }^{158}$ Other journals are freely available online. The changing nature of research also affects the way in which teachings are found. Today, teachings are going to be more widely read if they are available electronically and if they are available without charge.

\subsection{Blog posts}

A relative newcomer to the category of teachings, and arising out of the digital age, is the blog post. Blogs serve a variety of purposes, including informing readers of recent developments and subjecting those developments to critical analysis. ${ }^{159}$ They allow authors to test out their ideas; and enable readers to be reached more quickly than the print format allows, for example providing quick reactions to a judgment or event, or conducting symposia on recently published work. If they allow comments to be made on posts, blogs also enable a relative dialogue to take place.

\footnotetext{
153 The Editors, 'An Asian Journal of International Law' (2011) 1 Asian JIL 1.

${ }^{154}$ W Tieya and S Yee, 'Foreword' (2002) 1 Chinese JIL iii.

${ }^{155}$ L Mälksoo, Russian Approaches to International Law (OUP, 2015) 92 notes that, in the UN Audiovisual Library of International Law, German and Japanese international lawyers give their presentations in English, thus attracting a broader global audience. By contrast, most of the Russian international lawyers have presented in Russian, thus limiting the reach of their presentation.

${ }^{156}$ See https://www.icrc.org/en/international-review/overview.

157 Tieya and Yee, above note 154, iii.

${ }^{158}$ Bederman, above note 146, 58. See further Kirgis, above note 151, 574.

${ }^{159}$ See, eg, then Editor-in-Chief of the Leiden Journal of International Law, L van den Herik, 'Introduction: LIL in the Age of Cyberspace' (2012) 25 LJIL 1, 6, noting that 'law journals cannot compete with blogs as information providers'.
} 
There has been some discussion as to whether the quality of a blog post is less than that of a published article as they tend not to undergo blind peer review. ${ }^{160}$ One danger is that blogs 'make possible the repeated and systematic broadcast of non-expert opinions, opinion that can then be picked up and amplified by other non-expert blogs. ${ }^{161}$ However, that is more a critique of particular blogs, particular authors, or particular blog posts, rather than of the medium of blogging itself.

From the perspective of influence, one of the key features of blog posts is their potential to reach a broader audience than other legal writings. As with legal periodicals when they first emerged, blogs are designed to reach specialists as well as lay readers and practitioners as well as academics. ${ }^{162}$ Many readers, including journalists and lay readers, as well as academics and practitioners, might be willing to read a 500 word blog post rather than a 10,000 word article on the same issue. And blog posts do have influence. ${ }^{163}$

Ultimately, there are a number of different types of teachings, including digests, treatises, textbooks, monographs, commentaries, journal articles, and blog posts. Other categories, such as casebooks, and oral teachings, for example lectures and presentations, could be added. ${ }^{164}$ Different categories of teachings serve different purposes and appeal to different audiences. The idea that teachings of publicists should only identify and analyse state practice is thus to privilege a very particular type of writing and to overlook the multiple audiences of legal writings.

\section{Assessing influence}

As noted in the introduction, in days gone by, teachings of publicists were considered particularly influential in the development of international law. By contrast, it is commonly suggested that, by the start of the twenty-first century, teachings of publicists had become far less influential. 'Influence', though, is a rather tricky concept to pin down. It has been suggested that assessing the influence of teachings 'with any exactitude is almost impossible', ${ }^{165}$ a position which is surely correct.

\footnotetext{
${ }^{160}$ M Milanovic, 'Some Thoughts on the Serdar Mohammed Appeals Judgment', EJIL: Talk! Blog, 10 August 2015, available at http://www.ejiltalk.org/some-thoughts-on-the-serdar-mohammed-appeals-judgment/, indicating that the UK Government argued before the Court of Appeal that the Court should not refer to blog posts, as the lack of blind peer review makes posts less rigorous.

${ }^{161}$ B Leiter, 'Why Blogs are Bad for Legal Scholarship', The Yale Law Journal Forum, 19 September 2006, available at http://www.yalelawjournal.org/forum/why-blogs-are-bad-for-legal-scholarship. See also J d'Aspremont, 'In Defense of the Hazardous Tool of Legal Blogging', EJIL: Talk! Blog, 6 January 2011, available at http://www.ejiltalk.org/in-defense-of-the-hazardous-tool-of-legal-blogging/, who ultimately concludes that the hazards are outweighed by the virtues of blogging.

${ }^{162}$ See eg R Goodman and S Vladeck, 'Welcome to Just Security!', Just Security Blog, 23 September 2013 , available at https://www.justsecurity.org/965/security/, in which the authors note that they hope the blog will 'become a ready resource for decision-makers, analysts, and practitioners who address difficult U.S. national security law issues, and an invaluable reference for those simply trying to stay abreast of the daily developments in this ever-moving field.'

${ }^{163}$ For example, they are not infrequently cited by courts and tribunals. See eg Serdar Mohammed above note 14, paras 197, 208 and 241.

${ }^{164}$ The focus on teachings in written form seems to be due to the use of the term 'writings of publicists' as interchangeable with 'teachings of publicists', as well as the difficulties in becoming aware of teachings in oral form prior to changes in technology. Historically, it would also have been more difficult to prove that the view of a publicist was $X$ if the view had not been expressed in writing.

${ }^{165}$ W Twining, 'The Role of Academics in the Legal System', in M Tushnet and P Cane (eds), Oxford Handbook of Legal Studies (OUP, 2005) 926.
} 
However, a working notion of influence can be identified such as to assist with discussion of the present topic. Influence can be said to come about 'where something from A flows into and thereby affects $B^{\prime}{ }^{166}$ It needs to be distinguished from related concepts, in particular that of causation. Influence occurs 'where a person's outlook alters as a result of his or her conscious or subconscious noticing of some external stimulus. ${ }^{167}$

Thus, the influence of teachings of publicists cannot properly be assessed by looking at the teaching or the publicist alone. Therefore, the expertise of the publicist and the quality of his or her work, while important, are only part of the picture. In order properly to assess influence, the teaching must be considered in relation to those that receive it. Teachings of publicists have little to no influence in and of themselves. Even when an idea might be said to originate with a publicist, it does not become the law through the work of the publicist alone. It is only if and when the teaching is taken up by other actors that the teaching can be said to have influence. Were the idea not taken up by a state, a court, or another actor, it would remain at the level of an idea. The publicist is part of the community of international lawyers, ${ }^{168}$ and it is how actors within the community receive and use the writing that determines its influence. It is this interaction between publicists and other actors - which includes other publicists - that is important. The importance of the community of international lawyers thus extends beyond matters of interpretation to the making and shaping of international law more broadly. ${ }^{169}$ And teachings must be seen as part of the interaction between actors that are involved in the making and shaping of international law. ${ }^{170}$

Accordingly, there are two crucial elements to determining influence, in addition to the publicist and the teaching, namely the actors that receive the teaching and the interaction between the teaching and these actors. However, it is important to bear in mind that not all writings will be influential. Indeed, given the number of teachings on international law that are published each year, a relatively low percentage of teachings are likely to have proven influential.

\subsection{Actors being influenced}

The actors that receive the teaching are the various actors in the community of international lawyers. They thus include states, courts and tribunals, international organizations, treaty bodies, and so on. They also include other publicists, be they state-empowered entities, expert groups, or

\footnotetext{
${ }^{166}$ N Duxbury, Jurists and Judges: An Essay on Influence (Hart Publishing, 2001) 5.

167 Ibid, 6.

${ }^{168}$ The concept is related to, but differs from, the idea of the interpretive community, as it extends beyond matters of interpretation. On which, see M Waibel, 'Interpretive Communities in International Law', in A Bianchi, D Peat and M Windsor (eds), Interpretation in International Law (OUP, 2015) 147. Likewise, the concept is related to, but differs from, that of the epistemic community, a s there is no need for a shared episteme. On which, see A Bianchi, 'Epistemic Communities', in J D'Aspremont and S Singh (eds), Fundamental Concepts for International Law (Edward Elgar, 2016) [ssrn version]. It is perhaps most closely related to $O$ Schachter, 'The Invisible College of International Lawyers' (1977) 72 Northwestern University Law Review 217; and G Hernández, 'The Responsibility of the International Legal Academic: Situating the Grammarian within the "Invisible College"', in A Nollkaemper et al (eds), International Law as a Profession (CUP, forthcoming 2016).

${ }^{169}$ On the importance of the community of actors for questions of interpretation, see I Johnstone, 'Treaty Interpretation: The Authority of Interpretive Communities' (1990-1) 12 Michigan JIL 371; I Johnstone, 'The Power of Interpretive Communities', in M Barnett and R Duvall (eds), Power in Global Governance (CUP, 2004); Waibel, above note 158. See also I Venzke, How Interpretation Makes International Law (OUP, 2012).

${ }^{170}$ See, from a different perspective, d'Aspremont, above note 5, 210.
} 
ordinary publicists. The precise composition of the community of international lawyers varies depending on the subject matter at issue. Indeed, rather than a single community of international lawyers, there are, in fact, multiple communities of international lawyers. ${ }^{171}$ The community comprises all those who have expertise in the relevant issue. For example, insofar as a matter of international human rights law is concerned, the community would include states, regional human rights courts, UN human rights treaty bodies, special procedures, human rights non-governmental organizations, and academics. ${ }^{172}$ Depending on the specific issue under consideration, it might also include other actors such as general public international lawyers, trade lawyers, or military lawyers.

Each of the actors in the community of international lawyers uses teachings of publicists. States utilize teachings as 'shortcuts' given that they often have to act under time pressure. ${ }^{173}$ Government legal advisors turn to digests for precedents, for example, ${ }^{174}$ relying on teachings of publicists instead of undertaking the first hand work themselves. On one view, then, 'international law is made by the legal advisers of Foreign Offices ... depending very much on learned authors'. ${ }^{175}$ The teachings of publicists are thus used behind the scenes. They are also used publicly. Government legal advisors and other counsellors rely on teachings of publicists to support their arguments and lines of thinking. ${ }^{176}$ They are referred to in legal opinions, ${ }^{177}$ and in manuals. ${ }^{178}$ States refer to teachings in their pleadings before courts and tribunals. Teachings also influence states' positions, for example, in negotiations with other states.

Teachings are also used by courts and tribunals, both international and domestic. This is particularly evident from the judgments of courts and tribunals, in which teachings are cited. The citation of teachings is a matter that will be discussed further below. ${ }^{179}$

Publicists are also part of the community of international lawyers; and publicists influence other publicists. The tendency of publicists to refer extensively to the writings of other publicists in support of their arguments has been criticised. ${ }^{180}$ Indeed, at times, it can prove self-referential and self-serving. And many teachings of publicists seem to be read only by other publicists. ${ }^{181}$ At the same time, the potential influence of a shared view in the writings of publicists should not be underestimated. If the view of one highly regarded publicist is $X$, the fact that that view is shared by other highly regarded publicists can make a difference. As Chancellor Kent put it: 'in cases where the

\footnotetext{
${ }^{171}$ Waibel, above note $168,152-160$.

${ }^{172}$ See also J Tobin, 'Seeking to Persuade: A Constructive Approach to Human Rights Treaty Interpretation' (2010) 23 Harvard HRJ 1, 8-10.

${ }^{173}$ Simma, above note 7, 319.

${ }^{174}$ Sohn, above note 72, 399-401.

$175 \mathrm{lbid}, 401$. Sohn, at 399, also argues that international law is made by 'the professors, the writers of textbooks and casebooks, and the authors of articles in leading international law journals'.

${ }^{176}$ The point has been noted by former government legal advisors. See eg Wood, above note 6, para. 16; M Lachs, 'Teachings and Teaching of International Law' (1976-III) 151 RdC 161, 218-9.

${ }^{177}$ See eg Memorandum Opinion on the Geographic Scope of the Convention Against Torture and Its Application in Situations of Armed Conflict, from Harold Hongju Koh, Legal Advisor, U.S. Department of State, January 21, 2013, available at https://www.justsecurity.org/wp-content/uploads/2014/03/state-departmentcat-memo.pdf.

${ }^{178}$ See eg United States Department of Defense, Law of War Manual (June 2015).

${ }^{179}$ See below, Part 4.2.1.

${ }^{180}$ Eg O'Connell, above note 4, 35.

${ }^{181}$ See Twining et al, above note 165, 931.
} 
principal jurists agree, the presumption will be very great in favour of the solidity of their maxims' ${ }^{182}$ The influence of a shared view amongst publicists can be seen in the ICJ's references to 'all or nearly all writers', ${ }^{183}$ or 'general opinion', ${ }^{184}$ as well as its reference to splits amongst publicists. ${ }^{185}$ As with the work of expert groups, it becomes more difficult to argue that the legal position is $Y$ if publicists generally are of the view that the position is $X$ and have explained why this is the case. That being said, publicists are only part of the community of international lawyers. Thus, even if there is a shared view among publicists, that view needs to be considered alongside the views of other actors in the community of international lawyers, in particular, states.

The different categories of publicist should also be kept in mind when considering the influence of publicists on other publicists. The influence of one category of publicist on another, such as the influence of an individual publicist on the ILC, is important. For the ILC then develops the points made in the doctrine and uses the doctrine to shape its commentary, which can in turn influence, or even become, a later treaty provision. In this way "teachings" are ... further developed by "teachings".,186

\subsection{Interaction between teachings and actors}

The second key element for assessing influence is the interaction between the teaching and the relevant actor. It is this interaction that is the most difficult element to determine. Much of the interaction takes place behind closed doors, making it difficult to establish which particular teachings have been read. Even when that can be determined, for example, by establishing which teachings were included in bundles for judges as part of case files, or by tracing downloads of articles to particular servers in government, it is difficult to determine actual influence. Actors often do not explain their thought processes; and reading a teaching is not the same as being influenced by it, though in the broadest sense, we are all products of our experiences. Thus, signifiers of influence have to be identified and proxies for influence have to be used.

\subsubsection{Citation}

It is in this context that citation by courts and tribunals can prove useful. In many respects, citations can be viewed as proxies for influence, as a citation reveals the interaction between the judge and the writing.

Citations to teachings are commonplace in international law jurisprudence. Although the ICJ tends not to refer to ordinary publicists, on several occasions, it has referred to teachings of publicists

\footnotetext{
${ }^{182}$ The Paquete Habana, above note 8, 701. Kent continued, in a more questionable manner: 'and no civilized nation that does not arrogantly set all ordinary law and justice at defiance will venture to disregard the uniform sense of the established writers on international law'.

${ }^{183}$ The Case of the S.S. "Lotus", PCIJ Ser A No 10, p.26.

${ }^{184}$ Case of the S.S. "Wimbledon", PCIJ Ser A, No 1, p.28.

185 Lagrand Case (Germany $v$ United States of America), Provisional Measures [2001] ICJ Rep 466, 501 (referring to 'extensive controversy in the literature').

${ }^{186}$ Lachs, above note 176, 225. See also Stahn and De Brabandere, above note 17, 4.
} 
generally. ${ }^{187}$ Just occasionally, it does refer to individual publicists; ${ }^{188}$ and it makes not infrequent reference to the work of the International Law Commission. ${ }^{189}$ As is well-known, the teachings of publicists are cited in separate and dissenting opinions of judges. Other international courts and tribunals make greater reference to teachings of publicists. This is particularly prominent in certain fields, such as international criminal law and international investment law, in which reference tends to be made to teachings of publicists in the judgment or arbitral award. Certain national courts also refer to the teachings of publicists, often rather frequently. For their part, parties to cases make copious references to teachings in their arguments before a court. This suggests that 'litigants expect them to have some effect on the decision-maker's approach. ${ }^{190}$

Teachings of publicists are cited in different ways. They might be cited as authority for a particular view that is set forth in a judgment, relying on the position set out in the teaching to reach the relevant conclusion. This is the strongest form of influence but also the one that is the most difficult to establish. Teachings might be cited as confirmation of a conclusion reached, to support a view already held. In this form of citation, the teaching is used to buttress the conclusion and to indicate to the reader that others are of the same view. This is akin to the 'see also' cite in an academic publication. Indeed, in a different context, it has been suggested that 'scholarly articles are generally utilized in a superficial manner primarily to add academic authority to decisions ultimately based upon other grounds, rather than playing a significant role in the actual decision-making process. ${ }^{191}$ Teachings might also serve as a pointer to the reader for additional information. This is akin to the 'see further' cite. The teaching is cited in this sense if the judge is of the view that the reader might find it of value. Teachings can also be referenced to act as a counter-argument to the proposition set out, in order to demonstrate that all sides of the argument have been considered. This is akin to the 'compare' cite. It may or may not be followed with a statement as to why the teaching is incorrect. Teachings might be cited also for other reasons, for example, as a substitute for state practice; $;^{192}$ as an indication of the state of legal thinking on a matter; as a summary of the state of the law, conflicting or otherwise; or as 'a convenient locus for a well-established proposition'. ${ }^{193}$

Each of these forms of citation suggests that the teaching has influenced the court or tribunal, albeit the influence is of different types. However, citation is not the same as influence. ${ }^{194}$ For example, if a

\footnotetext{
${ }^{187}$ See eg PCIJ: The Case of the S.S. "Lotus", PCIJ Ser A No 10, p.26; Certain German Interests in Polish Upper Silesia, PCIJ Ser A No 6, p.20. See also ICJ: Nottebohm Case (Leichtenstein v Guatemala) (Second Phase) [1955] ICJ Rep 4, 22; Legality of the Threat or Use of Nuclear Weapons [1996] ICJ Rep 226, 259, para 85.

188 Land, Island and Maritime Frontier Dispute (EI Salvador/Honduras; Nicaragua intervening) [1992] ICJ Rep 351, 593, para. 394 (referring to the successive editors of Oppenheim's International Law and to G Gidel, Le droit international public de la mer (1934)); Application of the Convention on the Prevention and Punishment of the Crime of Genocide (Bosnia and Herzegovina v Serbia and Montenegro) [2007] ICJ Rep 43, 125 (referring to R Lemkin, Axis Rule in Occupied Europe (1944)).

${ }^{189}$ See generally, M Peil, 'Scholarly Writings as a Source of Law: A Survey of the Use of Doctrine by the International Court of Justice' (2012) 1 Cambridge Journal of International and Comparative Law 136. The work of the ILC is cited heavily also by international investment tribunals. See Cole, above note 141, 305.

${ }^{190}$ Thirlway, above note 143, 127.

${ }^{191}$ GS Crespi, 'The Influence of Two Decades of Contract Law Scholarship on Judicial Rulings: An Empirical Analysis' (2004) 57 SMU Law Review 105, 106.

${ }^{192}$ Crawford, above note 9, 43.

193 J Kammerhofer, 'Law-making by Scholars', in C Brolmann and Y Radi (eds), Research Handbook on the Theory and Practice of International Law-Making (Edward Elgar, 2016) [p.15 of ssrn version].

${ }^{194}$ Duxbury, above note 166, 14-15.
} 
judge asks a law clerk to footnote an opinion, the cited material did not influence the judge in coming to his or her conclusion. Conversely, teachings can influence courts and tribunals even without their being cited. Teachings might not be cited for a number of reasons, such as legal culture or not wanting to single out a particular author. This does not mean that judges and other actors have not read the teaching or that the teaching did not influence their decision. ${ }^{195}$ Likewise, particular teachings may be referenced for particular points, but there might not be citation to broader pieces that influenced the judge's general thinking on the matter or his or her approach to an issue.

It is difficult to determine why a particular teaching of a particular publicist was cited as opposed to a different teaching by another publicist. As discussed above, the eminence of a particular author, signified by factors such as reputation, expertise, and title carries weight, as does the quality of the work. ${ }^{196}$ There are also practical matters, such as whether the teaching was drawn to the attention of the court, for example by being cited in written pleadings or referenced in oral argument. How lawyers receive the work will thus be of particular importance and is an understated part of analyses of citations. Judicial decisions are greatly influenced by the arguments of counsel; indeed, in certain cases, a judicial decision might reflect acceptance of an argument of counsel. Accordingly, teachings will often need to influence lawyers before they will influence courts.

Citation of particular works can take on a life of their own. If a particular writing is cited on a few occasions, other courts, or the same court on different occasions, might prove more amenable to citing the work, in the knowledge that others have done so. Over time, citation of the work might become habit and it might even prove unusual not to cite the work. For example, not to see reference to the ILC's Articles on State Responsibility if a matter of state responsibility is at issue would be unusual.

Although a proxy for influence, and thus important, citation by courts and tribunals should not be the only way in which influence is measured. It tends to be considered because it is an easier and tangible form of ascertaining influence - tracking what is said rather than probing what is unsaid. As is evident from the above, though, counting citations has its faults and is partial at best. More importantly for present purposes, judges and arbitrators are only some of the members of the community of actors that make and shape international law. Citation by states in pleadings is equally important but more frequently overlooked. Accordingly, to focus on whether and how courts cite teachings only captures part of the picture. A focus on citation by courts and tribunals also privileges a common law way of thinking.

\subsubsection{Other interactions}

Citation is not the only signifier of influence. Other forms of interaction, and other proxies for influence, also exist. For example, treaties have been concluded on the basis of ILC draft Articles. In addition to those mentioned above, ${ }^{197}$ they include the Vienna Convention on the Law of Treaties between States and International Organizations or between International Organizations (1986), the Vienna Convention on Succession of States in respect of Treaties (1978), and the Convention on the

\footnotetext{
${ }^{195}$ Kammerhofer, above note 193, [p.16 of ssrn version].

196 See above, Part 2.3.

197 See above, Part 2.1.
} 
Reduction of Statelessness (1961). The work of the ILC very clearly influenced the structure, content, and language of these treaties. Likewise, the work of some expert groups has led to the conclusion of bilateral agreements that are based on the work of the expert group. ${ }^{198}$ Although less frequent, the writings of ordinary publicists have also led to the conclusion of treaties. Lemkin's role in the development of the concept of genocide and the Convention on the Prevention and Punishment of the Crime of Genocide is a case in point.

Moving away from conventional law, the ICRC's Study on Customary International Humanitarian Law led to a response being written by the United States. ${ }^{199}$ For present purposes, the fact that the response was somewhat critical of the Study is irrelevant. The publication of the Study caused a state to respond, presenting its critique of the Study and also its view of the law. In this way, the Study influenced the behaviour of a state. Writings of publicists have also led to the development of new norms, such as the right to development. ${ }^{200}$ Other writings, such as the Tallinn Manual on the International Law Applicable to Cyber Warfare, have emerged as the focal point on which discussions of the issue revolve.

\subsubsection{Pervasive influence}

Certain types of teachings have a pervasive influence, one that is more difficult to evidence. Textbooks, in particular, together with other writings that are used in legal education, present the best example of this broader influence. As has been written of the domestic context: '[c]ommon sense suggests that the most important single channel of influence of academic lawyers is through teaching future practitioners. ${ }^{201}$ To this could be added future academics.

The structure, substance, and approach of a textbook or a casebook can influence generations of students. These materials 'may be, at least for some law students, the only real exposure to international law methods, scholarship, and attitudes'. As such, they may be 'strikingly influential in forming the views and attitudes of practitioners and policymakers' ${ }^{202}$ Along similar lines, it has been noted that, in France:

'[t]he two most widely used general texts (précis) are those published by Dalloz and the Presses Universitaires de France. Under the pen of two great scholars, Charles Rousseau and Paul Reuter, these texts on the general principles of public international law have provided the first (and often the only) access to the discipline for many thousands of students and practitioners of public international law in France during the last fifty years. In a sense, these two précis have constituted the accepted wisdom on the subject for French readers. ${ }^{203}$

Whether a textbook or casebook is purely doctrinal, or includes discussion of inter alia feminist approaches to international law, third world approaches to international law, and economic analyses of international law, will likely affect students' views on the subject. Whether a work focuses on

\footnotetext{
${ }^{198}$ See above, Part 2.2.

199 JB Bellinger, III and WJ Haynes, II, 'A US Government Response to the International Committee of the Red Cross Study Customary International Humanitarian Law' (2007) 89 IRRC 443.

${ }^{200}$ See above, Part 2.3.

201 Twining, above note 165, 927. See also, on the international level, Lachs, above note 176, 214.

202 DJ Bederman, 'Review Essay, International Law Casebooks: Tradition, Revision, and Pedagogy' (2004) 98 AJIL 200, 200.

${ }^{203}$ De Mestral, above note 105, 553 (emphasis added).
} 
international cases or national ones will also affect perceptions of the subject. ${ }^{204}$ The content of an international law textbook, for example, whether it includes a chapter on space law or on international human rights law, conveys a sense of which issues form part of the core content of the subject. ${ }^{205}$ Likewise, how the teaching approaches substantive issues, such as the existence or otherwise of jus cogens norms and the nature of 'soft law', can influence the reader. Textbooks and casebooks thus figure prominently in a student's thinking of the subject, particularly when they are used at an impressionable and formative stage, for example in a student's first foray into the subject.

There is also a close relationship between the 'style of a legal system' and the 'manner in which its most prestigious lawyers are trained' ${ }^{206}$ As students move into their careers - as academics and practitioners - they take with them their views of international law that they first gleaned as students, shaped over time and with experience, and put them into practice. This can be seen, for example, in a professor adopting the same textbook that they used as a student, ${ }^{207}$ and former students citing writings of those who taught them. ${ }^{208}$ Textbooks can also influence other textbooks. ${ }^{209}$ And textbooks might be translated into a different language for use by a different audience, ${ }^{210}$ sometimes by former students.

The broad, pervasive influence of teachings is not limited to textbooks. Hernández has referred to the law-making potential of teachings, 'not through the formal processes of law-making, but rather, through the indirect law-creative potential that is exercised through cognising, structuring and apprehending legal materials'. ${ }^{211}$ On this view, a publicist serves as a 'grammarian', who 'shapes the formulation of arguments by other actors, prescribes the categories of acts, utterances and practices that will be deemed relevant and indeed contributes to the elaboration of the language'. ${ }^{212}$

\subsection{Non-linearity of influence}

The idea of influence was captured above in the sense of 'where something from A flows into and thereby affects $B^{\prime}{ }^{213}$ However, the relationship between writings and actors within the community of international lawyers is not always as neat or as linear as this would suggest.

The role of the publicist within the community of international lawyers is multifaceted. A publicist might set out his or her view of the law in a writing and then adopt the same position when

\footnotetext{
${ }^{204}$ Bederman, above note 202, 206. See further AE Roberts, Is International Law International? (OUP, forthcoming).

${ }^{205}$ See Roberts, ibid.

${ }^{206}$ Duxbury, above note 166, 104, referring to Max Weber, Economy and Society: An Outline of Interpretive Sociology, II, 784-808.

${ }^{207}$ See Roberts, above note 204.

208 Duxbury, above note 166, 20-1.

209 It has been noted that the 'organization' of Zhou Gengsheng, Guoji Fa (International Law) (Shangwu Yinshuguan, 1981) 'is primarily based on Oppenheim's treatise on international law, edited by H Lauterpacht'. See L Gross and H Chiu, Book Review (1983) 77 AJIL 977, 978.

${ }^{210}$ See, for example, Mälksoo, above note 155, 60-1, noting that there was a tradition of translating prominent West European works on international law ... under the late nineteenth century'.

${ }^{211}$ Hernández, above note 168 , [p.4 of ssrn version].

${ }^{212}$ Hernández, ibid, [p.3 of ssrn version].

${ }^{213}$ Duxbury, above note 166, 5.
} 
appointed as counsel, judge, or arbitrator. For example, there is a certain similarity between Antonio Cassese's view, expressed in his academic writings, that there is crime of terrorism in customary international law and the Interlocutory Decision of the Special Tribunal for Lebanon of which he was the primary author. ${ }^{214}$ In the investment context, an individual might be appointed an arbitrator, or not be appointed as an arbitrator, in part, because of the views he or she has previously expressed in teachings. And the position taken in the teaching might later be reflected in the arbitral award. In each of these cases, the influence of the pronouncement comes from its status as a judicial decision or an arbitral award. Nonetheless, it can be traced back to the position first expressed when the individual was a writer.

The multi-faceted nature of the publicist operates also in different ways. An individual might make the very same point in two different capacities - for example, as an individual publicist and as a state-empowered entity - but it is the statement in the capacity as a state-empowered entity that tends to be taken up and preferred. For example, it is Eide's report on the right to food in his capacity as Special Rapporteur that tends to be referenced, rather than his book chapter. ${ }^{215}$ In the case of the right to development, the idea was first set out in a writing of a publicist. However, it was the author's role in the Commission on Human Rights that enabled him to take the idea further. ${ }^{216}$ In other instances, an employee of a state-empowered entity might first publish a writing in his or her individual capacity before the entity later adopts the writing as its official position. This allows for others to react to the writing and allows the entity to benefit from the reactions prior to making its official position known. ${ }^{217}$

Teachings, particularly those of state-empowered entities, are also important for their internal influence and external effects. The ICRC, for example, uses its writings as reference points when it engages in discussion with, or provides training for, states. Likewise, in a number of states, UNHCR carries out refugee status determinations. When it does so, it utilizes its Handbook and other UNHCR documents. ${ }^{218}$ For the persons concerned, the writings of UNHCR can prove determinative of an issue.

Publicists are also influential outside specific writings. They might be consulted on their views, or they might provide advice, formal or informal, to a government or another member of the community of international lawyers. There is a long history of international lawyers combining teaching and practice. This was true of many of the founding fathers, such as Gentilis, Grotius, and Vattel; ${ }^{219}$ and continues today. Others combine teaching and government service or move back and forth between the two. They serve as external advisors, in-house lawyers, and experts. They act as counsel, consultants, and form part of a state's delegation at diplomatic conferences. Former

\footnotetext{
${ }^{214}$ Compare, for example, A Cassese, 'Terrorism as an International Crime', in A Bianchi (ed), Enforcing International Law Norms Against Terrorism (2004) with Interlocutory Decision on the Applicable Law: Terrorism, Conspiracy, Homicide, Perpetration, Cumulative Charging, Case No STL-11-01/I, 16 February 2011. 
students not infrequently consult their teachers to seek their views on particular matters. All this tends to be on the basis of the broader reputation of the publicist and their body of work rather than on a single writing, or on the basis of personal or professional connections. The influence of the publicist in this capacity can prove particularly significant. Mention can be made, for example, of Lauterpacht's contribution to the categorization of crimes in Article 6(c) of the Charter of the International Military Tribunal at Nuremberg and, specifically, the inclusion of crimes against humanity. ${ }^{220}$ The direct contribution to the development of the law comes from the other member of community rather than the publicist in their role as advisor. However, the publicist exercises a behind-the-scenes influence. The examples also demonstrate the close relationship between different members of the community of international lawyers.

The non-linearity extends to teachings themselves. Publicists are not always consistent in what they write. A publicist might change his or her mind on a matter, recanting an earlier position. Those who have taken up the initial view of the publicist might also recant their position or they might retain that view. Equally, the same publicist might publish one view as a matter of lex ferenda, in an effort to change the law, while publishing a different view as a statement of lex lata. For example, Thomas has noted that, in a note in the British Year Book of International Law, FA Mann argued for a particular understanding of fair and equitable treatment, one that was different to prior formulations of the standard. ${ }^{221}$ By contrast, in his monograph on The Legal Aspects of Money, Mann took a view that was consistent with the previously understood position. ${ }^{222}$ Thomas puts the difference down to 'the fact that in his treatise Mann was attempting to state de lege lata, as opposed to de lege ferenda. ${ }^{223}$ Yet, Thomas notes that it is Mann's British Year Book note that was picked up, and used, in the literature and by certain investment tribunals, rather than the views that he expressed in The Legal Aspects of Money. ${ }^{224}$

The influence of teachings is also a multi-stage process and does not stop once A has an impact on B. Teachings are particularly influential when there is a gap or uncertainty in the law, and that gap or uncertainty needs to be filled. Thus, they are used particularly frequently in newer areas of the law such as international criminal law and international investment law. Early case law in these areas tends to be full of references to writings. Over time, however, writings tend to be used less, with the early case law being cited for the relevant proposition instead of the writings from which the early cases drew. For example, in the investment context, the arbitral tribunal in Salini 'employed a checklist of criteria' that was 'nearly identical to' the features of 'investment' contained in Schreuer's Commentary. ${ }^{225}$ Over time, however, it is Salini that has become the key reference point on the issue

\footnotetext{
${ }^{220}$ See AF Vrdoljak, 'Human Rights and Genocide: The Work of Lauterpacht and Lemkin in Modern International Law' (2009) 20 EJIL 1163, 1189.

${ }^{221}$ JC Thomas, 'Reflections on Article 1105 of NAFTA: History, State Practice and the Influence of Commentators' (2002) 17 ICSID Review 21, 51-2, referring to FA Mann, 'British Treaties for the Promotion and Protection of Investments' (1981) LII BYBIL 241, 243.

222 Thomas, above note 221, 58, referring to FA Mann, The Legal Aspects of Money (4 ed, 1982) 510, expressing the same position as the third edition of the work, 1971, at 532.

${ }^{223}$ Thomas, above note $221,58$.

224 Ibid, 59.

225 J Mortensen, 'The Meaning of "Investment": ICSID's Travaux and the Domain of International Investment Law (2010) 51 Harvard International Law Journal 257, 272. Compare Salini Costruttori S.P.A. and Italstrade S.P.A. v Kingdom of Morocco, Case No ARB/004, Decision on Jurisdiction, para. 52 ((2003) 42 ILM 609), with CH Schreuer, The ICSID Convention: A Commentary (CUP, 2001) 140.
} 
rather than Schreuer's Commentary. Thus, one arbitral tribunal has observed that ' $\mathrm{t}] \mathrm{h}$ he factors considered in Salini are widely accepted as the starting point of an ICSID tribunal's analysis of whether there is an "investment" within the meaning of Article 25(1)' of the ICSID Convention. ${ }^{226}$ Indeed, it has become known as 'the Salini test' ${ }^{227}$ The example is particularly instructive given that Schreuer's Commentary was not in fact cited by the arbitral tribunal for the features of investment, though it was cited elsewhere in the award, reinforcing the point that lack of citation cannot be equated with lack of influence. Furthermore, the way in which the features of investment have been used, namely moving away from a 'descriptive list ... towards a set of mandatory legal requirements', has led Schreuer to write that ' $\mathrm{t}$ ] ]he First Edition of this Commentary cannot serve as authority for this development'. ${ }^{228} \mathrm{~A}$ teaching can thus take on a life of its own and be used in a way that is very different from that which the author intended.

The move from the citation of a teaching to the citation of a judicial decision or arbitral award reveals the relative weight of writings as compared with judicial decisions. It also reinforces why citation counts can be misleading. Indeed, '[w] hen the influence of a work becomes particularly profound, citations to it may decrease'. ${ }^{229}$ The point is not limited to judicial decisions. If the issue of exclusion zones in the law of armed conflict at sea is recalled, the writing of an individual publicist influenced the work of an expert group and the work of the expert group influenced states' military manuals. Today, reference is made to the state military manuals and the San Remo Manual rather than the Fenrick article which inspired them. Furthermore, as time goes by, the concept alone might be referenced, without an indication of where it originated - such as the idea of 'instant custom'. ${ }^{230}$ Alternatively, the concept might appear alongside the name of the originator but without reference to a particular writing - such as the 'Baxter paradox'. ${ }^{231}$ The irony is, then, that ' $[\mathrm{t}]$ he ideas of the greatest innovators are often considered not to require explicit citation because they have become embedded in our intellectual culture. ${ }^{232}$

\subsection{Limitations on the influence of writings}

The community of international lawyers is thus a necessary part of determining the influence of teachings of publicists. However, the community can deliberately or subconsciously privilege certain teachings and limit the use of others. Membership of the community of international lawyers 'entails the internalisation of a common set of background assumptions and disciplinary rules which are accepted by other international lawyers as valid. ${ }^{233}$ One consequence of this is that teachings will have to speak the language of the community and accept its strictures in order to be influential.

\footnotetext{
${ }^{226}$ Malaysian Historical Salvors Sdn, Bhd v The Government of Malaysia, ICSID Case No. ARB/05/10, Award on Jurisdiction, para. 74.

${ }^{227}$ See eg Mr Saba Fakes v Republic of Turkey, ICSID Case No. ARB/07/20, Award, para. 103.

${ }^{228}$ CH Schreuer et al, The ICSID Convention: A Commentary (CUP, 2 ed, 2009) 133.

${ }^{229}$ Duxbury, above note 166, 15.

${ }^{230}$ Attributed to Bin Cheng: B Cheng, 'United Nations Resolutions on Outer Space: "Instant" International Customary Law ?' (1965) 5 Indian JIL 23.

${ }^{231}$ Originating out of the idea that 'as the number of parties to a treaty increases, it becomes more difficult to demonstrate what is the state of customary international law dehors the treaty.' RR Baxter, 'Treaties and Custom' (1970-I) 129 Recueil des Cours 27, 64.

232 Duxbury, above note 166, 15.

${ }^{233}$ Hernández, above note 168, 6. See further J d'Aspremont, 'Wording in International Law' (2012) 25 LJIL 575 , 586-7.
} 
Teachings that do not speak the language, or which are considered disruptive, might be overlooked, dismissed, pigeon-holed, or otherwise not valued. This is particularly true of work that challenges mainstream thinking or seeks to overturn orthodoxies.

Reactions to the presentation of a paper by Charlesworth, Chinkin and Wright, which led to their ground-breaking article, 'Feminist Approaches to International Law', ${ }^{234}$ is a good example of the potentially constricting effect of the community of international lawyers. Their account of the reactions is worth quoting in full:

'The reaction to our paper was mixed. Several people were enthusiastic, while many of the audience looked discomfited and embarrassed (perhaps on our behalf!). One senior figure in the Australian international law community said in the discussion following the paper that the ideas were quite unrealistic as they would mean enlarging the scope of international law and depriving our discipline of its distinctive character. Some of our colleagues advised us to get back to "real world" international law for the sake of our careers. Another type of reaction was interest in the paper as an intriguing academic sideshow. Afterwards we found that we began to be asked to appear at symposia and on panels to present what were seen as controversial and contentious feminist ideas, but that the ideas were rarely taken up or engaged with. As the three of us became more closely associated with "feminist approaches to international law" our colleagues were sometimes rather disconcerted if we spoke on international law issues without taking an explicitly feminist approach. It seemed that we had created a splash without waves. ${ }^{235}$

Another example of the potentially restrictive effect of the community of international lawyers relates to the writings on third world approaches to international law (TWAIL). ${ }^{236}$ Anghie and Chimni have observed that 'TWAIL has ... found it difficult to assert itself in an institutional setting which, when it is not generally uncomprehending of TWAIL's history and its aims, seeks to incorporate TWAIL into a familiar geography of alliances and rivalries' and have noted further that 'scholarship cannot be separated from the institutional resources - law schools, journals, publishers - that enable its production. ${ }^{237}$

Part of the reason for this is that the community of international lawyers serves as the gatekeeper and has the potential to value only those teachings that are in its mould. Accordingly, the success of a publicist's argument will be influenced by 'his technical prowess in balancing his political agenda with the vocabulary and form acceptable to other actors who also engage with international law.'238

\footnotetext{
${ }^{234} \mathrm{H}$ Charlesworth, C Chinkin and S Wright, 'Feminist Approaches to International Law' (1991) 85 AJIL 613.

${ }^{235}$ C Chinkin, S Wright and H Charlesworth, 'Feminist Approaches to International Law: Reflections from Another Century', in D Buss and A Manji (eds), International Law: Modern Feminist Approaches (Hart Publishing, 2005) 17, 17-8. See also H Charlesworth, 'Alienating Oscar? Feminist Analysis of International Law', in DG Dallmeyer (ed), Reconceiving Reality: Women and International Law (ASIL, 1993) 1.

${ }^{236}$ Postcolonial or Third World Approaches to International Law did not feature in the leading AJIL symposium on method in international law, an omission that was put down to an 'error of ignorance rather than deliberate exclusion'. See HJ Richardson III, 'Correspondence' (2000) 94 AJIL 99 and the reply thereto, at 101. See further A Anghie and BS Chimni, 'Third World Approaches to International Law and Individual Responsibility in Internal Conflicts' (2003) 2 Chinese JIL 77.

${ }^{237}$ Anghie and Chimni, ibid, 87.

${ }^{238}$ Hernández, above note 168, 27.
} 
This, in turn, has the potential to stymie the influence of the most dissonant thinking, to make it more difficult to overturn orthodoxies, and to stifle radically different voices and styles. Aspects of the discipline, such as peer review and the growing importance of citation counts, reinforce the constraints and also militate against radical challenges to orthodoxies.

Alternatively, the community of actors can become fragmented, with chasms created whereby teachings no longer speak to certain members of the community. Teachings then prove to be of interest and use only to subsets of the community and there might be relatively little substantive engagement between the various subsets. For example, writing in 2005, Charlesworth observed that 'looking at the major writings in international law and theory over the past decade, it is very hard to detect any real attempt to engage with feminist theories of international law, or indeed with any outsider perspectives. ${ }^{239}$ And in the United States, a split has emerged between writings of publicists and the judiciary, with Chief Justice Roberts noting that law review articles are not 'particularly helpful for practitioners or judges'. ${ }^{240}$ In this way, writings of publicists can lose some of their influence.

\section{Conclusion}

The 'teachings of publicists' is a heterogeneous category, including teachings and publicists of different types. Insofar as publicists are concerned, it includes entities that have been empowered by states to produce teachings; experts groups, standing and ad hoc; and ordinary publicists. Teachings are also made up of different types, and include digests, treatises, textbooks, monographs, commentaries, journal articles, and blog posts. All are of different types, have different goals in mind, and appeal to different audiences. Teachings of publicists should thus not be limited either to the individual publicist or to the repository of state practice.

The influence of teachings of publicists is difficult to assess. It includes, but is not limited to, an assessment of citation by courts and tribunals. Citation is one useful measure of determining influence, but citation does not necessarily mean influence and lack of citation certainly does not mean lack of influence. More importantly for present purposes, focus on citation by courts and tribunals privileges the role of these bodies in the development of international law and downplays the role of other actors, such as states, international organisations, and treaty bodies. It also understates the more pervasive influence of teachings, such as on the structure of the discipline, and on students of international law, who constitute later generations of international lawyers. Instead, influence should be assessed by reference to how all the actors within the community of international lawyers use or do not use the teachings of publicists. Individual publicists do not create law by themselves. Rather, they constitute a part of the community that does create the law. Thus, it is the interaction between teachings and the members of the community of international lawyers that is determinative of influence.

\footnotetext{
${ }^{239} \mathrm{H}$ Charlesworth, 'Feminist Ambivalence about International Law' (2005) 11 International Legal Theory 1, 2.

${ }^{240}$ Cited in DL Schwartz and L Petherbridge, 'The Use of Legal Scholarship by the Federal Court of Appeals: An Empirical Study' (2011) 96 Cornell L Rev 1345, 1347. See also HT Edwards, 'The Growing Disjunction between Legal Education and the Legal Profession' (1992-3) 91 Michigan Law Review 34.
} 
When seen in this light, it is evident that teachings of publicists continue to have an important influence on the making and shaping of international law. The precise nature of the influence varies considerably. It includes the publicist as the originator of ideas, as the finessor of norms, and as the 'grammarian'. ${ }^{241}$ The influence also varies by publicist. The balance between the influence of teachings of state-empowered entities and ordinary publicists has changed, ${ }^{242}$ with the former proving particularly significant. Ordinary publicists continue to play a crucial role, but their role is different to times past. Utlimately, as Wolfke put it: 'the influence of doctrine on the formation of international law in general is certainly rather behind-the-scenes and anonymous. To disregard it would, however, be to say the least, unjustified. ${ }^{243}$

\footnotetext{
${ }^{241}$ Hernández, above note 168.

${ }^{242}$ Stahn and De Brabandere, above note 17, 4.

${ }^{243}$ Wolfke, above note 3, 76.
} 